\title{
Foraging ecology of male Cerulean Warblers and other Neotropical migrants
}

\author{
Gregory A. George \\ West Virginia University
}

Follow this and additional works at: https://researchrepository.wvu.edu/etd

\section{Recommended Citation}

George, Gregory A., "Foraging ecology of male Cerulean Warblers and other Neotropical migrants" (2009). Graduate Theses, Dissertations, and Problem Reports. 2835.

https://researchrepository.wvu.edu/etd/2835

This Dissertation is protected by copyright and/or related rights. It has been brought to you by the The Research Repository @ WVU with permission from the rights-holder(s). You are free to use this Dissertation in any way that is permitted by the copyright and related rights legislation that applies to your use. For other uses you must obtain permission from the rights-holder(s) directly, unless additional rights are indicated by a Creative Commons license in the record and/ or on the work itself. This Dissertation has been accepted for inclusion in WVU Graduate Theses, Dissertations, and Problem Reports collection by an authorized administrator of The Research Repository @ WVU.

For more information, please contact researchrepository@mail.wvu.edu. 
Foraging ecology of male Cerulean Warblers and other Neotropical migrants

\author{
Gregory A. George
}

Dissertation submitted to the

Davis College of Agriculture, Forestry, and Consumer Sciences at West Virginia University in partial fulfillment of the requirements for the degree of

\author{
Doctor of Philosophy \\ in
}

Forest Resources Science

Petra Bohall Wood, Ph.D., Chair James T. Anderson, Ph.D. Gerald R. Hobbs, Ph.D.

Patrick D. Keyser, Ph.D.

Susan Philhower Raylman, Ph.D.

Division of Forestry and Natural Resources

\author{
Morgantown, West Virginia \\ 2009
}

Keywords: American Redstart, Black-and-white Warbler, Cerulean Warbler, foraging bias, Hooded Warbler, Red-eyed Vireo, Scarlet Tanager, tree species use 


\title{
ABSTRACT
}

Foraging ecology of Neotropical migrants, with concentration on male Cerulean Warblers

\author{
Gregory A. George
}

Understanding foraging ecology provides insight into species resource requirements and overall conservation needs. We examined foraging behavior and tree species selection of male Cerulean Warblers (Dendroica cerulea) $(\mathrm{n}=673)$ in response to varying degrees of habitat disturbance from silvicultural treatments at four study sites in West Virginia, Kentucky and Ohio, during the 2006 and 2007 breeding seasons. Cerulean Warblers foraged primarily in the forest canopy, along branch tips by gleaning insects off leaf surfaces, often adjacent to canopy gaps, both pre- and post-harvest. Tree species availability, based on importance values (IV) calculated from density, frequency and basal areas, differed from tree species used for foraging both pre- and post-harvest $(\mathrm{p}<0.01)$. Preferred species included hickory (Carya spp.), sugar maple (Acer saccharum), and chestnut oak (Quercus prinus), although red oak (Quercus rubra) was strongly avoided. Tree species selection changed little post-harvest in all silvicultural treatments. Aerial foraging increased after harvests. Cerulean Warblers exhibited selection preferences, suggesting, maintaining availability of preferred tree species is important for management of Cerulean Warbler populations.

Species resource requirements are an important component of habitat selection. We investigated foraging ecology and tree species selection of five Neotropical migrant species ( $\mathrm{n}=$ 679); American Redstart (Setophaga ruticilla), Black-and-white Warbler (Mniotilta varia), Hooded Warbler (Wilsonia citrine), Red-eyed Vireo (Vireo olivaceus), and Scarlet Tanager (Piranga olivacea) at three study sites in West Virginia during breeding seasons of 2006 and 2007. We analyzed influences of habitat disturbance from silvicultural treatments implemented during the non-breeding season between years. Tree species availability, based on importance values (IV) calculated from relative density, frequency, and basal area, differed from tree species used for foraging pre and post-treatment. Species varied in their preferred maneuver types and degree of tree species selectivity. Aerial maneuvers increased post-treatment for all species except Black-and-white Warblers. At the guild level, sugar maples were preferred and red oaks were avoided. Tree species selection changed little post-harvest. Red-eyed Vireos and postharvest American Redstarts exhibited significant tree species selection preferences $(\mathrm{P}<0.05)$ although Scarlet Tanagers were near-significant in tree species selection $(\mathrm{P}=0.06)$.

Foraging ecology studies could be biased due to disparity in initial detection probabilities of foraging birds among tree species or foraging behaviors because it might be easier to detect a foraging bird when it is in certain tree species, lower in the canopy, or using aerial foraging maneuvers. Our study investigated whether the initial foraging observation is biased based on 1521 paired, single-point foraging observations for six species of arboreal foraging Neotropical migrants in two study sites in West Virginia and one in Kentucky in 2006 and 2007. We did not detect a significant difference in tree species used for foraging between the initial and second foraging observation $(\mathrm{P} \geq 0.62)$. Foraging maneuvers and foraging height generally were not significantly different $(\mathrm{P} \geq 0.09)$ between the two foraging observations for the six avian species tested. We conclude that the initial detection of foraging birds would not have a major influence on interpretation of foraging substrate or behavioral preferences. 


\section{ACKNOWLEDGEMENTS}

I thank my graduate committee for all their help throughout the process of creating this dissertation. I thank Dr. Petra Wood for endlessly fielding questions from research design to analysis and especially for her patience in explaining the process of writing for scientific publication. I thank Dr. James Anderson for his meticulous comments on early drafts and his ability to ask open-ended questions that make a student think and I thank Dr. Gerald Hobbs for comments on statistical procedures. I thank Dr. Patrick Keyser for viewing my work from the perspective of a forester and biologist, keeping a concerted eye in management applications. I thank Dr. Susan Philhower Raylman for her perspective as a behavioral ecologist. I thank the late Dr. George Seidel who taught me to approach statistics slowly but deliberately and inspired me to tackle the topic in detail, making me a better biologist in the end.

I am grateful to my funding sources: National Fish and Wildlife Foundation, National Council for Air and Stream Improvement, U.S. Fish and Wildlife Service, West Virginia Division of Natural Resources, Kentucky Department of Fish and Wildlife Resources, Ohio Department of Natural Resources, and U.S. Forest Service Monongahela National Forest. Additional logistic support was provided by the U.S. Forest Service Monongahela National Forest, West Virginia Division of Natural Resources, Advantage Timberland, Forest Land Group and Wagner LTD.

This research would not have been possible without the dedication of several field station supervisors including Vanessa Lane, Patrick McElhone, Matt Shumar, and Mathew White. Additionally, over two dozen field technicians were involved with data collection.

I thank my family for all of their support and understanding over the past few years. I especially thank my wife, Felicia. Although completing two graduate degrees of her own, she always found additional time to support my work and help me with logistics, like having seemingly endless lines of field technicians staying in our small home while we prepared to start 
the field seasons. Her support combined with the comic-relief of our dog, Toby, helped to keep me grounded during those times when deadlines approached.

Lastly, I thank Dr. Terry Master, from East Stroudsburg University, and all of the research staff at Hawk Mountain Sanctuary, especially Dr. Keith Bildstein and Laurie Goodrich. Then have mentored me from when I was 19 years old, interested in bird watching but not so much in academics, until now, 34 with a desire to be a better biologist and, perhaps, enter academia myself. They have donated time and energy to this transformation. I have learned more from these three individuals than all of my academic coursework combined, for that opportunity I am grateful. 


\section{TABLE OF CONTENTS}

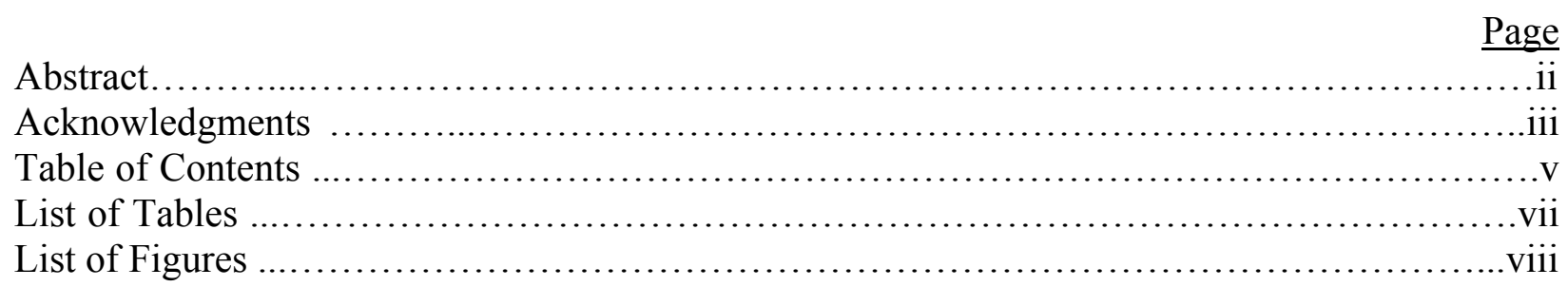

Chapter 1: Literature Review of Cerulean Warblers and Neotropical Migrant Foraging Ecology

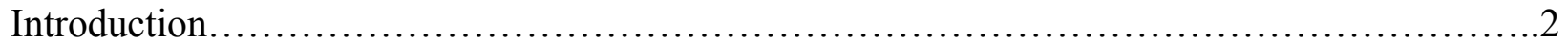

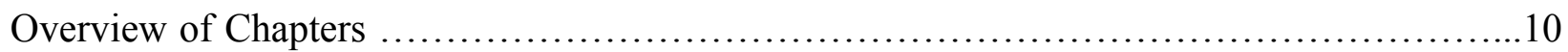

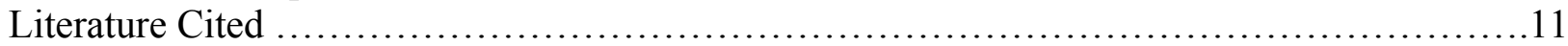

Chapter 2: Influence of silviculture on male Cerulean Warbler (Dendroica cerulean) foraging ecology and tree species selection.

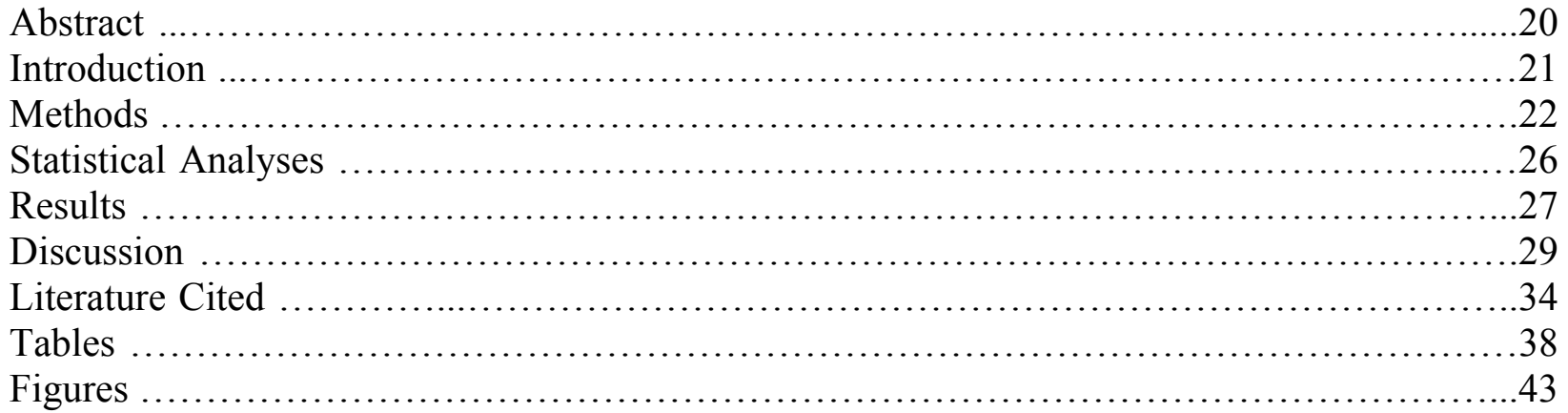

Chapter 3: Foraging ecology and tree species selection of five Neotropical migrants in West Virginia.

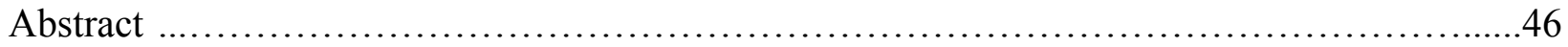

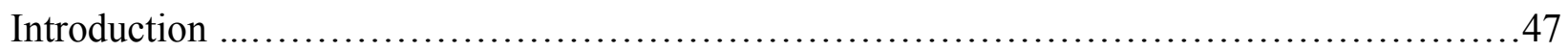

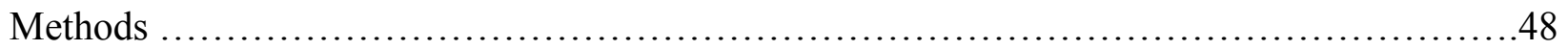

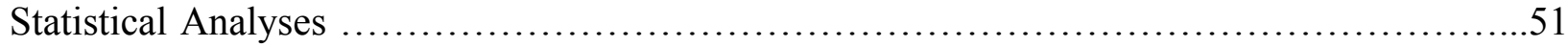

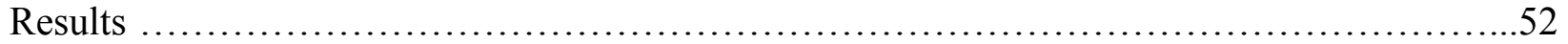

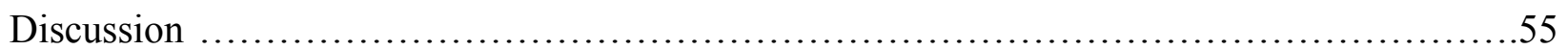

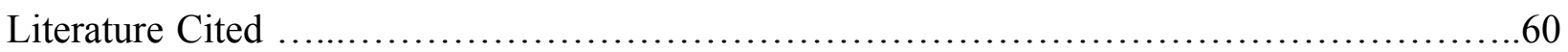

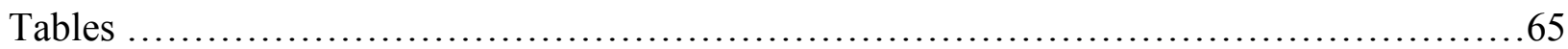


Chapter 4: Analysis of observer detection bias in avian foraging behavior and tree species use.

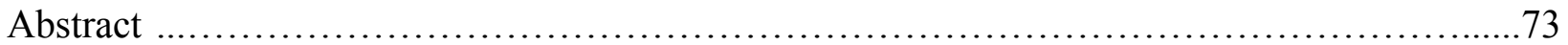

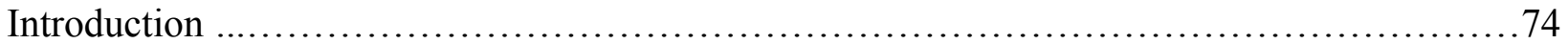

Methods ........................................................................ 75

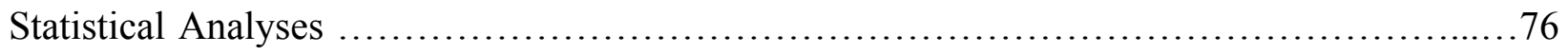

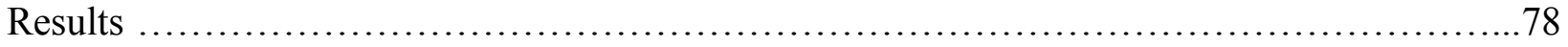

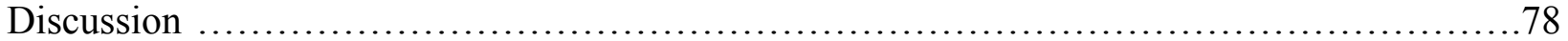

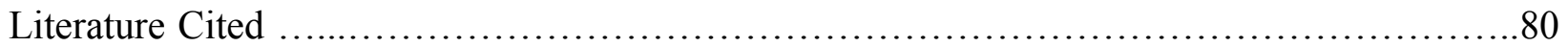

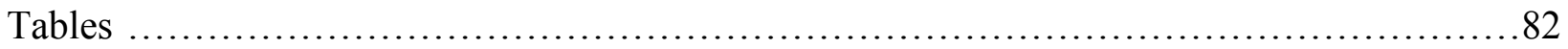

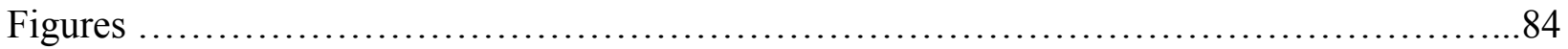




\section{LIST OF TABLES}

Table 1: Total number of observations by study site and year for the pre- (2006) and posttreatment (2007) seasons. One year of data was collected at the Ohio site, REMA, during the 2007, post-treatment, season

Table 2: Percent availability of forest structure was proportionately similar between years. Data from two West Virginia and the Kentucky study areas combined .....

Table 3: Comparison of foraging variables within uncut forest, light harvest, and intermediate harvest treatments combining the Daniel Boone National Forest, Lewis-Wetzel Wildlife Management Area , and Wagner study sites for the pre- (2006) and post-treatment (2007) seasons. Included are Fisher's exact tests comparing pre- and post-treatment years to discern difference between years by harvest type. Paired chi-square tests were used to discern which foraging categories were different from pre- to post- harvest with $\alpha=0.01$ for significance.

Significant results denoted by asterisk

Table 4: Cerulean Warbler tree species preference and avoidance values for uncut forests, light harvest, and intermediate harvests combining the West Virginia and Kentucky study areas for pre- (2006) and post-treatment (2007). Preference and avoidance are indicated by positive and negative values, respectively. Observed versus expected values were compared with chi-square goodness-of-fit test with Monte Carlo estimates for p-values

Table 5: Tree species availability, based on Importance Values (IV), was generally similar between years within the light and intermediate harvest, represented here by percent change between years. Data from three study areas in West Virginia and Kentucky combined.

\section{CHAPTER 3:}

Table 1: Total number and percent of observations for each species by foraging variable for all study areas and plots combined. Data are presented for the pre-harvest (2006) and post-harvest (2007) years. Focal species are American Redstart (AMRE), Black-and-white Warbler (BAWW), Hooded Warbler (HOWA), Red-eyed Vireo (REVI), and Scarlet Tanager (SCTA)

Table 2: Comparison of foraging maneuver use between pre- (2006) and post-harvest (2007) years for uncut forest and harvested area (low and intermediate harvests combined) combining the study sites. Included are P-values for Fisher's exact tests comparing pre- and post-treatment years to discern difference between years by forest or harvest area. Paired chi-square tests were used to discern which foraging categories were different from pre- to post- harvest with $\alpha=0.01$ for significance. Significant results denoted by asterisk......................................66

Table 3: Comparison of forest structure use between pre- (2006) and post-harvest (2007) years for uncut forest and harvested area (low and intermediate harvests combined) combining the study sites. Included are P-values for Fisher's exact tests comparing pre- and post-treatment years to discern difference between years by forest or harvest area. Paired chi-square tests were 
used to discern which foraging categories were different from pre- to post- harvest with $\alpha=0.01$

for significance. Significant results denoted by asterisk

Table 4: Comparison of forest gap use between pre- (2006) and post-harvest (2007) years for uncut forest and harvested area (low and intermediate harvests combined) combining the study sites. Included are P-values for Fisher's exact tests comparing pre- and post-treatment years to discern difference between years by forest or harvest area. Paired chi-square tests were used to discern which foraging categories were different from pre- to post- harvest with $\alpha=0.01$ for significance. Significant results denoted by asterisk.

Table 5: Tree species preference index combining all avian species and plots for the Lewis Wetzel and Wyoming study sites for the pre- (2006) and post-treatment (2007) seasons

Table 6: Tree species preference index for each harvest treatment for all avian species and plots for the Lewis-Wetzel and Wyoming study sites for the pre- (2006) and post-treatment (2007) seasons.. Focal species are American Redstart (AMRE), Black-and-white Warbler (BAWW), Hooded Warbler (HOWA), Red-eyed Vireo (REVI), and Scarlet Tanager (SCTA). All species were combined for analysis

Table 7: Tree species preference index for each avian species pre- and post-harvest. Included are Chi-square analysis with Monte Carlo simulated p-values comparing observer and expected frequencies of tree species use by five Neotropical migratory songbirds. Focal species are American Redstart (AMRE), Black-and-white Warbler (BAWW), Hooded Warbler (HOWA), Red-eyed Vireo (REVI), and Scarlet Tanager (SCTA) ................................ 71

\section{CHAPTER 4:}

Table 1: Within-year variation in tree species selection between the first and second foraging observations for each study site by year.

Table 2: Variation in maneuver use and foraging height between paired foraging observations by species and year. The Cochran-Mantel-Haenszel test $\left(\mathrm{M}^{2}\right)$ accounted for variation among study sites.

\section{Chapter 1:}

\section{LIST OF FIGURES}

Figure 1: Study area locations in West Virginia, Ohio, and Kentucky. Blue areas represent breeding range, dark blue is the core range, based on Breeding Bird Survey data (Sauer at al. 2008)

Figure 2: Light treatment harvest (residual basal area of $14.5-24.3 \mathrm{~m}^{2} / \mathrm{ha}$ ) at Lewis-Wetzel study area in West Virginia (Photo Credit: Patrick McElhone)

Figure 3: Intermediate treatment harvest (residual basal area of $11.5-17.1 \mathrm{~m}^{2} / \mathrm{ha}$ ) at LewisWetzel study area in West Virginia (Photo Credit: Gregory George) 
Figure 4: Heavy treatment harvest (residual basal area of 3.0-9.6 $\mathrm{m}^{2} / \mathrm{ha}$ ) at Wyoming County study area in West Virginia (Photo Credit: Gregory George)

\section{Chapter 2}

Figure 1: Pre-treatment $(2006, \mathrm{n}=312)$ and post-treatment $(2007, \mathrm{n}=316)$ indices of tree species selection and avoidance for the 12 most available tree species. Indices based on West Virginia and Kentucky study areas combined. Hickory and red oak categories are comprised of all members of their respective groups due to inconsistencies in tree species identification.......43

Figure 2: Similarities in tree diameter at breast height $(\mathrm{DBH})$ use $(\mathrm{n}=315)$ compared to availability $(n=1855)$ indicate that Cerulean Warblers select trees irrespective of diameter based on boxplots depicting each samples five-number summary (includes: minimum, maximum, Q1,

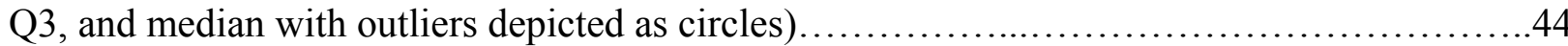

\section{Chapter 4:}

Figure 1: Distribution of Cerulean Warbler foraging observations among tree species at LewisWetzel Wildlife Management Area for 2007. The distribution did not differ for the first versus second observation $\left(\mathrm{M}^{2}=16.4, P=0.80\right)$ at any study site for either year $\ldots \ldots \ldots \ldots \ldots \ldots \ldots . . . . . .64$

Figure 2: American Redstart use of foraging maneuvers differed between the paired observations

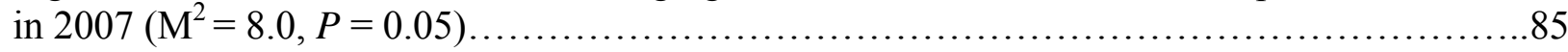


CHAPTER 1

INTRODUCTION 
Cerulean Warblers (Dendroica cerulea), once common, have declined at a net rate of 4.1\% per year from 1966 through 2007 (Sauer et al. 2008). Although they have recently expanded in parts of their range, the species appears to be declining primarily in the core of their breeding range (Jones et al. 2004, Sauer et al. 2008). Partners in Flight has ranked the Cerulean Warbler second overall, in the Northeast region, for species warranting immediate conservation action (Rosenberg and Wells 2000). Consequently, Cerulean Warblers are a focal species for conservation efforts (Hamel et al. 2004).

Life history information on the Cerulean Warbler is limited, particularly as it pertains to foraging ecology. Yet, understanding foraging behavior can provide insight into the ecology of Neotropical migrants and can shed additional light on their requirements and thus on their overall conservation needs (Petit et al. 1995). Rosenberg et al. (2000) found regular use of multiple tree species in West Virginia for foraging and singing by the Cerulean Warbler such as Chestnut Oak (Quercus prinus), Red Oak (Q. rubra), Maples (Acer spp.), Hickories (Carya spp.), and White Oak (Q. alba) with nine other species, such as Tulip Poplar (Liriodendron tulipfera), used less frequently. However, these data were qualitative and did not examine availability of tree species. Gabbe et al. (2002) investigated tree species use versus availability in southern Illinois and found Cerulean Warblers to be highly selective of hickory species while avoiding others, such as tulip poplar. Lepidoptera larva, an important prey item for Cerulean Warblers, varies by tree species (Holmes and Schultz 1988); this variation could result, potentially, in tree species selectivity. Gleaning insects from leaves appears to be the primary method of food acquisition (Hamel 2000b). Hamel (2000b) describes typical foraging microhabitat locations being in the canopy near dense clusters of leaves where Cerulean Warblers navigate along tree branches looking at upper and lower leaf surfaces. In general, however, Hamel (2000b) identified foraging habitat and ecology as a priority research topic. 
Cerulean Warbler population response to silvicultural treatments could provide vital habitat use and conservation information. Few studies have examined response of Cerulean Warblers to silvicultural treatments (Wood et al. 2005). No studies have investigated the effects of silvicultural treatments, and the associated change in forest structure and composition on Cerulean Warbler foraging behavior, yet timber harvesting is a substantial portion of the economy in the core range of the species (Childs 2005). This study examined the response of Cerulean Warblers to silvicultural practices resulting in varying degrees of habitat disturbance in relation to their foraging resource requirements within their core breeding range (Figure 1).

\section{LITERATURE REVIEW}

\section{FORAGING ECOLOGY AND HABITAT USE AND SELECTION}

Cerulean Warbler.-- Cerulean Warblers are a small, insectivorous, Neotropical migrant that breeds in mature deciduous forests of eastern North America and winters along the Andean montane subtropical forests of northern South America (Hamel 2000b). Basic, yet vital, information on the biology and ecology of the Cerulean Warbler needs to be gathered with respect to their entire annual cycle including breeding, stopover, and wintering habitat (Rappole 1995, Hamel 2000b). Currently, evidence suggests that Cerulean Warbler populations are declining as a result of habitat loss or degradation on the breeding and wintering grounds (Hamel 2000b). Significant loss of appropriate habitat during any part of their annual cycle can result in a decrease in Cerulean Warbler populations (Rappole 1995, Sherry and Holmes 1995). Steep declines in populations resulted in a petition, in 2006, to the U.S. Department of the Interior, Fish and Wildlife Service (USFWS) requesting that the Cerulean Warbler be listed as "threatened" under the Endangered Species Act of 1973 (Hamel et al. 2004). The USFWS ruled that listing of Cerulean Warblers was not warranted because the species will not be endangered in all of, or a 
significant part of, its range within the foreseeable future even with the assumption that the rate of decline (-4.1\% per year) remained constant.

Loss of mid-elevation montane forests in the Andes Mountains is greater than any other forested habitat type in that region (Robbins et al. 1992). Cerulean Warblers do use shade grown coffee plantations, survival comparisons are needed between plantations and interior forest (Jones et al. 2000). Survival estimates suggest that events on wintering grounds are responsible for most adult male mortality and that current reproductive fitness is not adequate to offset adult mortality (Jones et al. 2004). Habitat loss along migratory stopover locations also could be important but information pertaining to the migratory period is lacking with one exception from the Mayan Mountains of Belize (Parker 1994). Parker (1994) observed large numbers of Cerulean Warblers along the lower montane forests in early April suggesting that such habitat could be important migratory staging areas.

On the breeding grounds, Cerulean Warblers also are facing habitat loss. Historically, Cerulean Warblers were primarily associated with mature floodplain forest (Hamel 2000b). This habitat type experienced substantial losses as floodplain forests have largely been converted to farmland; currently mature mesic upland forests are selected (Hamel 2000b). Amidst the species' overall decline, there has been some range expansion into Ontario. This, in part, could be due to abandoned farmland succeeding into mature forests (Oliarnyk and Robertson 1996). Veit et al. (2005) compared individuals from areas of population expansion with those from declining populations to quantify variation in microsatellite loci. Based on their work, the Cerulean Warbler population decline does not appear to have affected genetic variation within the species.

Habitat use and selection.-- Habitat use and selection have important ramifications for survival of a species because both influences reproductive and mortality rates (Petit et al. 1995). The evolutionary significance of habitat selection is reflected in the close association between 
habitat use and morphology, behavior, and life history traits of a species (Cody 1985). An understanding of habitat use and ecological requirements thus forms the framework for conservation efforts of all species (Cody 1985, Probst and Crow 1991).

The study of habitat selection has received considerable attention (Jones 2001). Morse (1985) explains that habitat structure could be essential to habitat selection and that sensitivity to habitat variation differs among warbler species. Habitat models have been created to explain patterns in species abundance and distribution (MacArthur and Pianka 1966, Rosenzweig 1991). Habitat selection can be influenced by landscape structure (Odum 1950, Karr and Freemark 1983, Holmes et al. 1986, Greenberg et al. 1995, and Petit and Petit 1996). Hunt (1998) found that the pattern of habitat succession in Vermont and New Hampshire resulted in more mature forest and less early successional habitat which affected American Redstart (Setophaga ruticilla) populations.

Cerulean Warblers prefer mature deciduous forests with a diverse canopy structure including tall, large diameter trees with an open understory (Hamel 2000b). Cerulean Warbler population densities are positively associated with large amounts of mature deciduous forest in the landscape (Bosworth 2003). Large populations occur in floodplain forests as well as a variety of mesic uplands (Lynch 1981, Hamel 2000b, Rosenberg et al. 2000). Habitat selection could be opportunistic, where individuals select the most mature forests available in that region (Hamel 2000a). Generally, territories include large trees that create dense foliage and high canopies (Jones and Robertson 2001). Jones et al. (2001) found that the species exhibits a degree of habitat plasticity in response to natural habitat disturbance. The species is known to select second-growth forests while being sensitive to forest fragmentation (Oliarnyk and Robertson 1996). Weakland and Wood (2005) found territory density to be greater in intact forest compared to fragmented forests. Perkins (2006) determined gaps to be important in Cerulean 
Warbler territory selection, although Barg et al. (2005) found no consistent correlation between core use areas and location of canopy gaps.

Morphological foraging adaptations and patchy distribution of resources might result in a foraging preference for certain tree species in various songbirds (Holmes and Robinson 1981, Parrish 1995a, b). Foraging habitat use and selection has not been thoroughly evaluated for Cerulean Warblers. Gabbe et al. (2002) quantified tree species use by thirteen foraging insectivorous passerines in southern Illinois. Most species foraged in tree species disproportional to availability. Yellow-throated Warblers (Dendroica dominica) and the Cerulean Warblers were the most selective. Although Cerulean Warblers exhibited a strong preference towards hickory trees in Illinois, this may not be representative over the entire Cerulean Warbler range and, therefore, additional investigation is warranted.

Response to silviculture.--Response of avian abundance, distributions, and overall reproductive fitness to variability in forest structure is lacking (Marzluff et al. 2000). Forest vegetation structure is an important and well known component of avian habitat selection (MacArthur and MacArthur 1961, Cody 1968, Brown 1992, Petit and Petit 1996, Jones 2001). Forests are dynamic systems with varying micro-habitat characteristics associated with different stages of succession. Selection of suitable habitat is often tied to these different stages of succession (Hunt 1998). Silvicultural practices can imitate natural disturbance regimes and create a more diverse habitat mosaic (Greenberg et al. 1995). Understanding that some species prefer certain stages of forest succession allows forest management to be tailored to meet the habitat requirements of particular species (Probst and Weinrich 1993). Warbler abundance can vary by species to the different silvicultural practices (Freedman et al. 1981, Duguay et al. 2001, McDermott 2007, McDermott and Wood 2008). Franzreb (1983), comparing logged and natural environments, found habitat alteration influenced tree species selection and foraging height of birds in Arizona. Tree species selection by avifauna varied due to modifications of availability 
resulting from selective tree species removal. Aspen was not removed from the logged areas and use increased from 5\% to 53\%. In harvested areas, the canopy was removed completely resulting in overall decreased foraging height.

Hamel (2000b) suggested that managed forests with diverse vertical forest structure due to implementation of selective harvests have canopy gaps that might increase the occurrence of suitable breeding habitat for Cerulean Warblers. Wood et al. (2005) suggested that lack of a diverse vertical forest structure from regenerating clearcuts resulted in lower use by Cerulean Warblers than regenerating harvests with residual canopy trees.

There is some concern that silvicultural practices could result in a decrease in songbird survival rates due to increased nest predation and Brown-headed Cowbird (Molothrus ater) parasitism (Paton 1994, Brittingham and Temple 1996). In heavily forested landscapes, however, Brown-headed Cowbird parasitism is less common than in forest tracts located in more agricultural areas (Duguay et al. 2001).

The effects of forest management on avian ecology and conservation contain gaps of understanding and implementation (Thompson et al. 2000). Timber production is a primary land use in West Virginia. If implemented with a conservation objective, a forest management treatment, such as a selective cut, could theoretically mimic tree fall gaps that appear to be preferred by Cerulean Warblers (Oliarnyk and Robertson 1996, Hamel et al. 2004). However, there has not been an empirical study specifically examining Cerulean Warbler response to silvicultural practices. Information gaps in the scientific literature can be addressed based on carefully designed observational studies followed by manipulative experiments (Thompson et al. 2000). This information can then be analyzed for causation rendering it more valuable to the formation of functional management recommendations (Sallabanks et al. 2000).

Mature forest stands often are retained adjacent to harvest areas resulting in a diverse habitat mosaic. Many Neotropical migrants have a negative association with forest openings 
while others show either indifference or respond positively (Morse 1985, Thompson et al. 2000, Germaine et al. 1997). Different silvicultural treatments influence invertebrate distributions, the major food source for Neotropical migratory birds (Summerville and Crist 2002, Duguay et al. 2000). This could have important ramifications considering that Lepidoptera are the most common and diverse group of invertebrates in eastern deciduous forests (Hammond and Miller 1998, Summerville et al. 1999). Kilgo (2005) found a decrease in arthropod abundance and Hooded Warbler foraging rate from forest edge to interior forest (defined as $>100 \mathrm{~m}$ ). Kilgo (2005) concluded that Hooded Warblers encountered less prey, and therefore, foraged less proficiently near group-selection harvest gaps. These influences could be compounded further by many characteristics of invertebrates (i.e., stage of life cycle, activity level, and cryptic coloration) that can influence rate of selection by foraging individuals (Royama 1970, Cooper and Whitmore 1990, Majer et al. 1990).

Increased primary productivity associated with increased light levels found in canopy gaps might result in increased food availability (Fogden 1972). A warmer microclimate associated with increased light levels can result in increased abundance and activity of flying insects (Blake and Hoppes 1986, Smith and Dallman 1996, Gorham et al. 2002). Additionally, nitrogen is an important limiting factor in growth of invertebrate herbivores (Mattson 1980, Scriber and Slansky 1981, Mattson et al. 1991, Fortin and Mauffette 2002). Increased light levels are correlated with increased levels of nitrogen within leaves (Hemming and Lindroth 1995, Fortin and Mauffette 2002) potentially resulting in an increase in food availability for foraging birds.

Methodology.-We collected two single-point foraging observations. The idea of a second observation being compared to the first to quantify differential rates of visibility among tree species is lacking in the foraging literature. A similar argument was made to ignore the first 
foraging maneuver observed while analyzing the second and subsequent maneuvers to reduce bias (Hejl et al. 1990) so applying similar reasoning to substrate selection is, perhaps, relevant.

Research was conducted in 2006 and 2007 at two study sites in West Virginia and one in Kentucky. Additionally, in 2007, data were collected at a study site in Ohio and an additional study site in West Virginia. Study sites included the Lewis Wetzel Wildlife Management Area (LWWMA) in Wetzel County, West Virginia, forested private timberlands in Wyoming County, West Virginia (Wagner), Monongahela National Forest (MON) in Randolph County, West Virginia, Daniel Boone National Forest (DBNF) in Bath and Menifee counties, Kentucky, and the Raccoon Ecological Management Area (REMA) in Vinton County, Ohio (Figure 1). All study sites are within the core of the species range (Hamel 2000).

Four, 20 ha, plots were placed along ridge-tops on northern and eastern aspects at each site. Each plot was generally rectangle shaped and had two, 5 ha, uncut buffers located on the plot ends and a central 10 ha block that received a timber harvest treatment. The treatment area was randomly assigned one of four timber harvesting treatments including an unharvested control, a light treatment similar to a single tree selection harvest (Figure 2), an intermediate treatment approximating a shelterwood harvest (Figure 3), and a heavy treatment approximating a deferment harvest (Figure 4). Respective residual basal area (RBA) per treatment type was $14.5-24.3 \mathrm{~m}^{2} / \mathrm{ha}, 11.5-17.1 \mathrm{~m}^{2} / \mathrm{ha}$, and $3.0-9.6 \mathrm{~m}^{2} / \mathrm{ha}$. The treatment mosaic resulted in three, 10 ha segments receiving a timber harvest and a combined 50 ha of uncut forest at each site. Timber harvests were implemented in fall and winter of 2006.

Because of the concurrent silvicultural study, we are presented with an opportunity to quantify response of Neotropical migratory songbirds to typical silvicultural treatments. In addition to the Cerulean Warbler, foraging observations were recorded for Hooded Warbler (Wilsonia pusilla), Black-and-white Warbler (Mniotilta varia), American Redstart (Setophaga ruticilla), Red-eyed Vireo (Vireo olivaceus), and Scarlet Tanager (Piranga olivacea). 


\section{Objectives}

The purpose of this research was to examine foraging behaviors and foraging habitat use versus availability of Cerulean Warblers during the breeding season. Information on tree species preference, foraging height, and temporal variation will assist in quantifying some of the basic ecological information that is lacking, but necessary, for sound habitat management. Specificly I examined if:

1) Cerulean Warblers select tree species proportional to availability.

2) selection of foraging substrate or behavior of Cerulean Warblers are influenced by silvicultural practices.

3) following foraging individuals to an additional tree reduces substrate bias in foraging observations.

4) silvicultural practices influence patterns of Neotropical migratory songbird habitat selection and foraging behavior.

\section{Overview of Chapters}

This dissertation has been written in the form of 4 chapters. The first chapter provides the introduction, literature review, research justifications, and project objectives. The second chapter covers the foraging ecology of Cerulean Warblers. The third chapter covers the foraging ecology of the additional five species for which foraging observations were collected. The last chapter covers the attempt to identify observer bias in avian foraging observation based research projects. The last three chapters are written in the style of a targeted scientific journal and will be submitted to the following journals.

Chapter 2- Conservation Biology

Chapter 3- Wilson Journal of Ornithology 


\section{LITERATURE CITED}

Barg, J. B., J. Jones, and R. J. Robertson. 2005. Describing breeding territories of migratory passerines: suggestions for sampling, choice of estimator, and delineation of core areas. Journal of Animal Ecology 74:139-149.

Blake, J. G., and W. G. Hoppes. 1986. Influence of resource abundance on use of tree-fall gaps by birds in an isolated woodlot. Auk 103:328-340.

Bosworth, S. B. 2003. Cerulean Warbler Relative Abundance and Frequency of Occurrence Relative to Large-scale Edge, Master's Thesis, West Virginia University.

Brittingham, M. C., and S. A. Temple. 1996. Vegetation around parasitized and non-parasitized nest within deciduous forests. Journal of Field Ornithology 67:406-413.

Brown, V. K. 1992. The effects of change in habitat structure during succession in terrestrial communities. Pp. 141-168 in (S. Bell, E McCoy and H. Mushinsky, eds.) Habitat structure: the physical arrangement of objects in space. Chapman and Hall, London, England.

Childs, R. A. 2005. West Virginia's Forests: Growing West Virginia'sFuture. Bureau of Business and Economic Research, College of Business and Economics, West Virginia University. Pp 1-14.

Cody, M. L. 1985 (ed.). Habitat selection in birds. Academic Press, San Diego, CA.

Cooper, R. J., and R. C. Whitmore. 1990. Arthropod sampling methods in ornithology. Pp 2937 in (M. Morrison, C. Ralph, J. Verner, and J. Jehl, Jr. eds.) Studies in avian biology No:13. Avian foraging: Theory, methodology and application. Cooper Ornithological Society.

Duguay, J. P., P. B. Wood, and G. W. Miller. 2000. Effects of timber harvest on invertebrate biomass and avian nest success. Wildlife Society Bulletin 28:1123-1131.

Duguay, J. P. P. B. Wood, and J. V. Nichols. 2001. Song bird abundance and avian nest survival rates in forests fragmented by different silvicultural treatments. Conservation Biology 15:1405-1415.

Fogden, M.P.L., 1972. The seasonality and population of equatorial forest birds in Sarawak. Ibis 114:307-342.

Fortin, M. and Y. Mauffette. 2002. The suitability of leaves from different canopy layers for a generalist herbivore (Lepidoptera: Lasiocampidae) foraging on sugar maple. Canadian Journal Forest Research. 32:379-389.

Franzreb, K. E. 1983. A comparison of avian foraging behavior in unlogged and logged mixedconiferous forests. Wilson Bulletin 95:60-76. 
Freedman, B., C. Beauchamp, I. A. McLaren, and S. I. Tingley. 1981. Forestry management practices and populations of breeding birds in a hardwood forest in Nova Scotia. Canadian Field-Naturalist 95:307-311.

Gabbe, A. P., S. K. Robinson,, and J. D. Brawn. 2002. Tree-species preferences of foraging Insectivorous Birds: Implications for floodplain forest restoration. Conservation Biology 16:462-470.

Germaine, G. G., S. H. Vessy, and D. E. Capen. 1997. Effects of small forest openings on the breeding bird c community in a Vermont hardwood Forest. Condor 99:708-718.

Gorham, L. E., S. L. King, B. D. Keeland, and S. Mopper. 2002. Effects of canopy gaps and flooding on homopterans in a bottomland hardwood forest. Wetlands 22:541-549.

Greenberg, C. H., L. D., Harris, and D. G. Neary. 1995. A comparison of bird communities in burned and salvaged-logged, clearcut, and forested Florida sand pine scrub. Wilson Bulletin. 107:40-54.

Hamel, P. B. 2000a. Cerulean Warbler status assessment. U.S. Fish \& Wildlife Service, Minneapolis, MN.

Hamel, P. B. 2000b. Cerulean Warbler (Dendroica cerulea). In The Birds of North America, No. 511 (A. Poole and F. Gill, eds.). The Birds of North America, Inc., Philadelphia, PA.

Hamel, P. B., D. K. Dawson, and P. D. Keyser. 2004. How can we learn more about the Cerulean Warbler (Dendroica cerulea). Auk 121:7-14.

Hammond P. C., and J. C. Miller. 1998. Comparison of the biodiversity of Lepidoptera within three forested ecosystems. Annals of the Entomological Society of America 91:323-328

Hej1, S. J., J. Verner, and G. W. Bell. 1990. Sequential versus initial observation in studies of avian foraging. Pp 166-173 in (M. Morrison, C. Ralph, J. Verner, and J. Jehl, Jr. eds.) Studies in avian biology No:13. Avian foraging: Theory, methodology and application. Cooper Ornithological Society.

Hemming, J.D.C., and Lindroth, R.L. 1995. Intraspecific variation in aspen phytochemistry: effects on performance of gypsy moths and forest tent caterpillars. Oecologia 103:79-88.

Holmes, R. T. and S. K. Robinson. 1981. Tree species preference of foraging insectivorous birds in a northern hardwood forest. Oecologia 48:31-35.

Holmes, R. T. and J. C. Schultz. 1988. Food availability for forest birds: effects of prey distribution and abundance on bird foraging. Canadian Journal of Zoology 66:720-728.

Holmes, R. T., T. W. Sherry, and F. W. Sturges. 1986. Bird community dynamics in a temperate deciduous forest: long term trends at Hubbard Brook. Ecological Monographs 56:201220 . 
Hunt, P. D. 1998. Evidence from a landscape population model of the importance of early successional habitat to the American Redstart. Conservation Biology 12:1377-1389.

Jones, J. 2001. Habitat selection studies in avian ecology: a critical review. Auk 118:557-562.

Jones, J., R. D. DeBruyn, J. J. Barg, and R. J. Robertson. 2001. Assessing the effects of natural disturbance on a Neotropical migrant songbird. Ecology 82:2628-2635.

Jones, J., and R. J. Robertson. 2001. Territory and nest-site selection of the Cerulean Warblers in eastern Ontario. Auk 118:727-735.

Jones, J., J. J. Barg, T. S. Sillett, M. L. Veit, and R. J. Robertson. 2004. Minimum estimates of survival and population growth for Cerulean Warblers (Dendroica cerulea) Breeding in Ontario, Canada. Auk 121:15-22.

Jones, J., P. R. Perazzi, E. H. Carruthers, and R. J. Robertson. 2000. Sociality and foraging behavior of the Cerulean Warbler in Venezuelan shade-coffee plantations. The Condor 102:958-962.

Karr, J. R. and K. E. Freemark. 1983. Habitat selection and environmental gradients: Dynamics in the 'Stable' tropics. Ecology 64:65-71.

Kilgo, J. C. 2005. Harvest-related edge effects on prey availability and foraging of hooded warbler in a bottomland hardwood forest. Condor 107:627-636.

Lynch, J. M. 1981. Status of the Cerulean Warbler in the Roanoke River basin of North Carolina. Chat 45:29-35.

MacArthur, R. H. and J. W. MacArthur. 1961. On bird species diversity. Ecology 42:594-598

MacArthur, R. H. and E. R. Pianka. 1966. On optimal use of a patchy environment. American Naturalist 100:603-609.

Majer, J. D., H. F. Recher, W. S. Perriman, and N. Achuthan. 1990. Spatial variation of invertebrate abundance within the canopies of two Australian eucalypt forests. Pp 65-72 in (M. Morrison, C. Ralph, J. Verner, and J. Jehl, Jr. eds.) Studies in avian biology No:13. Avian foraging: Theory, methodology and application. Cooper Ornithological Society.

Marzluff, J. M., M. G. Raphael, and R. Sallabanks. 2000. Understanding the effects of forest management on avian species. Wildlife Society Bulletin 28:1132-1143.

Mattson W. J. JR. 1980. Herbivory in relation to plant nitrogen content. Annual Reviews in Ecology and Systematics 11:119-161.

Mattson, W.J., R.A. Haack, R. K. Lawrence and S. S. Slocum. 1991. Considering the nutritional ecology of the spruce budworm in its management. Forest Ecology and Management 39: $183-210$. 
McDermott, M. E. 2007. Breeding and post-breeding forest bird community dynamics in regenerating clearcuts and two-age harvests in the central Appalachians. Master's Thesis, West Virginia University.

McDermott, M. E. and P. B. Wood. 2008. Short- and long-term implications of clearcut and two-age silviculture for conservation of breeding forest birds in the central Appalachians, USA. Biological Conservation 142:212-220.

Morse, D. H. 1985. Habitat selection in North American parulid warblers. Pp 131-157 in (M. L. Cody ed.) Habitat selection in birds. Academic Press, San Diego, CA.

Odum, E. P. 1950. Bird populations of the Highlands (North Carolina) Plateau in relation to plant succession and avian invasion. Ecology 31:587-605.

Oliarnyk, C. J. and R. K. Robertson. 1996. Breeding behavior and reproductive success of Cerulean Warblers in southeastern Ontario. Wilson Bulletin. 108:673-684.

Parker III, T. 1994. Habitat, behavior, and spring migration of the Cerulean Warbler in Belize. American Birds 48:70-75.

Parrish, J. D. 1995a. Effects of needle architecture on warbler habitat selection in a coastal spruce forest. Ecology 76:1813-1820.

Parrish, J. D. 1995b. Experimental evidence for intrinsic microhabitat preferences in the Blackthroated Green Warbler. Condor 97:935-943.

Paton, P. W. 1994. The effect of edge on avian nest success: how strong is the evidence? Conservation Biology 8:17-26.

Perkins, K. A. 2006. Cerulean Warbler Selection of Forest Canopy Gaps, Master's Thesis, West Virginia University.

Petit, D. R., J. F. Lynch, R. Hutto, J. G. Blake, and R. B. Waide. 1995. Habitat Use and Conservation in the Neotropics. Pp. 145-197 in (T. Martin and D.Finch, eds.). Ecology and Management of Neotropical Migratory Birds: A Synthesis and Review of Critical Issues.. Oxford University Press, New York, NY.

Petit, L. J. and D. R. Petit. 1996. Factors governing habitat selection by Prothonotary Warblers: Field tests on the Fretwell-Lucas models. Ecological Monographs 66:367-387.

Probst, J. and T. Crow. 1991. Integrating biological diversity and resource management. Journal of Forestry: 89:12-17.

Probst, J. R. and J. Weinrich. 1993. Relating Kirtland's warbler population to changing landscape composition and structure. Landscape Ecology 8:257-271.

Rappole, J. H. 1995. The ecology of migrant birds. Smithsonian Institution Press. Washington D.C. 
Robbins, C. S., J. W. Fitzpatrick, and P. B. Hamel. 1992. A warbler in trouble: Dendroica cerulea. Pp 549-562 In (J. Hagan III and D. Johnston, editors). Ecology and conservation of Neotropical migratory landbirds. Smithsonian Institution Press, Washington.

Rosenberg, K. V., S. E. Barker, and R. W. Rohrbaugh. 2000. An atlas of Cerulean Warbler populations. Final report to USFWS: 1997-2000 breeding seasons. Cornell Lab of Ornithology, Ithaca, NY.

Rosenberg, K. V., and J. V. Wells. 2000. Global perspectives on Neotropical migrant conservation in the Northeast: Long-term responsibilities vs. immediate concern. In (R.E. Bonney, D. Pashley, R.J. Cooper, and L.Niles Eds.) Strategies for bird conservation: The Partners in Flight planning process. Cornell Lab of Ornithology.

Rosenzweig, M. L. 1991. Habitat selection and population interactions: The search for mechanism. American Naturalist 137 (Supplement.):5-28.

Royama, T. 1970. Factors governing the hunting behavior and selection of food by the Great Tit, Parus major. Journal of Animal Ecology 39:619-660.

Sallabanks, R., E. B. Arnett, and J. M. Marzluff. 2000. An evaluation of research on the effects of timber harvest on bird populations. Wildlife Society Bulletin 28:1144-1155.

Sauer, J. R., J. E. Hines, J. Fallon. 2008. The North American Breeding Bird Survey, Results and Analysis 1966-1999. Version 5.15.2008, USGS Patuxent Wildlife Research Center, Laurel, Md.

Scriber, J.M., and F. Slansky, Jr. 1981. The nutritional ecology of immature insects. Annual Review of Emtomology 26:183-211.

Sherry, T. W. and R. T. Holmes. 1995. Summer versus winter limitations of populations: What are the issues and what is the evidence? Pp 85-120 in (T. Martin and D.Finch, eds.). Ecology and Management of Neotropical Migratory Birds: A Synthesis and Review of Critical Issues.. Oxford University Press, New York, NY.

Smith, R. and M. Dallman. 1996. Forest gap use by breeding Black-throated Green Warblers. Wilson Bulletin 108:588-591.

Summerville, K. S., J. J. Jacquot, and R. F. Stander. 1999. Preliminary checklist of the moths of Butler County, Ohio. Ohio Journal of Science 99:66-76.

Summerville, K. S. and T. O. Crist. 2002. Effects of timber harvest on forest Lepidoptera: community, guild, and species response. Ecological Applications, 12:820-835.

Thompson, F. R., J. D. Brawn, S Robinson, J. Faaborg, and R. L. Clawson. 2000. Approaches to investigate effects of forest management on birds in eastern deciduous forests: How reliable is our knowledge? Wildlife Society Bulletin 28:1111-1122.

Veit, M. L., R. J. Robertson, P. B. Hamel and V. L. Friesen. 2005. Population genetic structure and dispersal across a fragmented landscape in cerulean warblers (Dendroica cerulea). Conservation Genetics 6:159-174. 
Weakland, C. A. and P. B. Wood. 2005. Cerulean Warbler (Dendroica cerulea) microhabitat and landscape-level habitat characteristics in southern West Virginia. Auk 122:497-508.

Wood, P. B., J. P. Dugauy, and J. V. Nichols. 2005. Cerulean Warbler use of regenerated clearcut and two-age harvests. Wildlife Society Bulletin 33:851-858. 


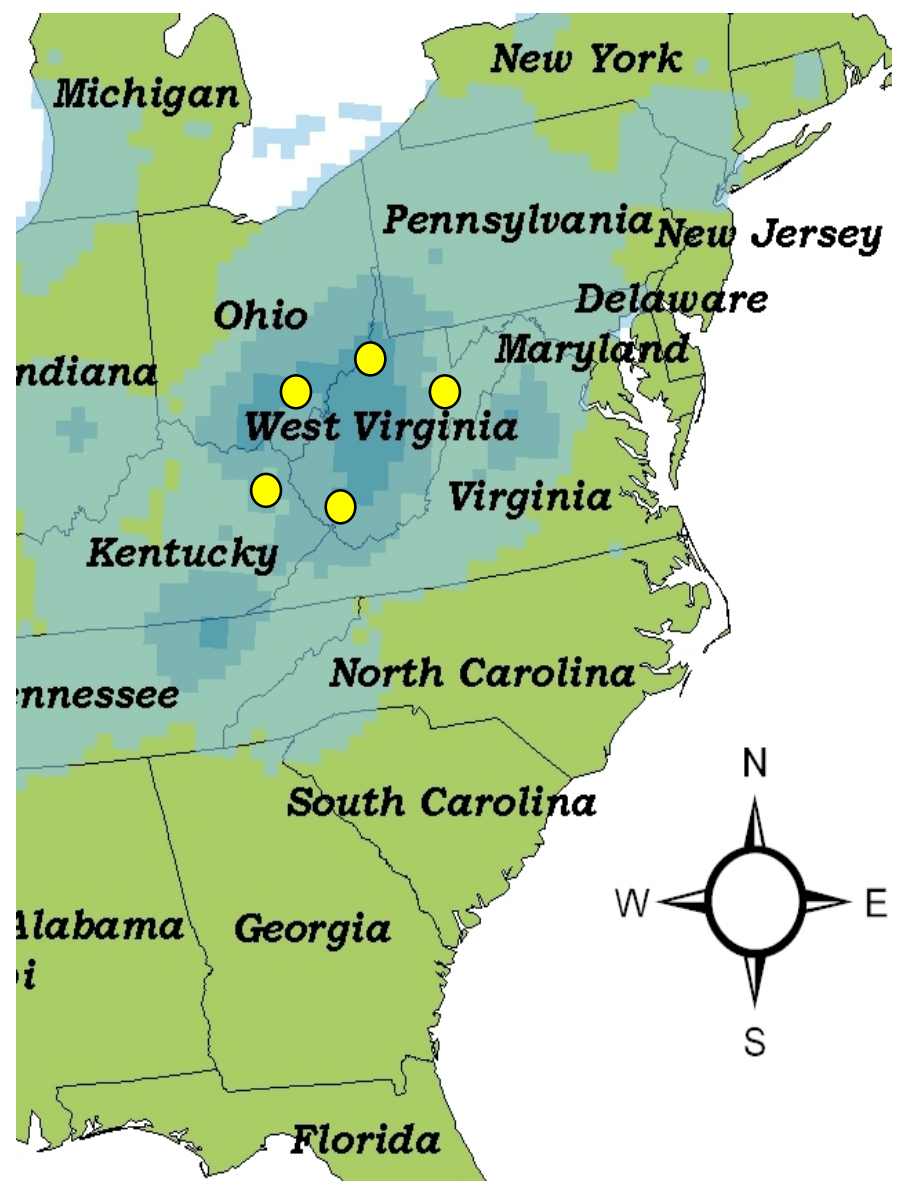

Figure 1: Study area locations in West Virginia, Ohio, and Kentucky. Blue areas represent breeding range, dark blue is the core range, based on Breeding Bird Survey data (Sauer at al. 2008).

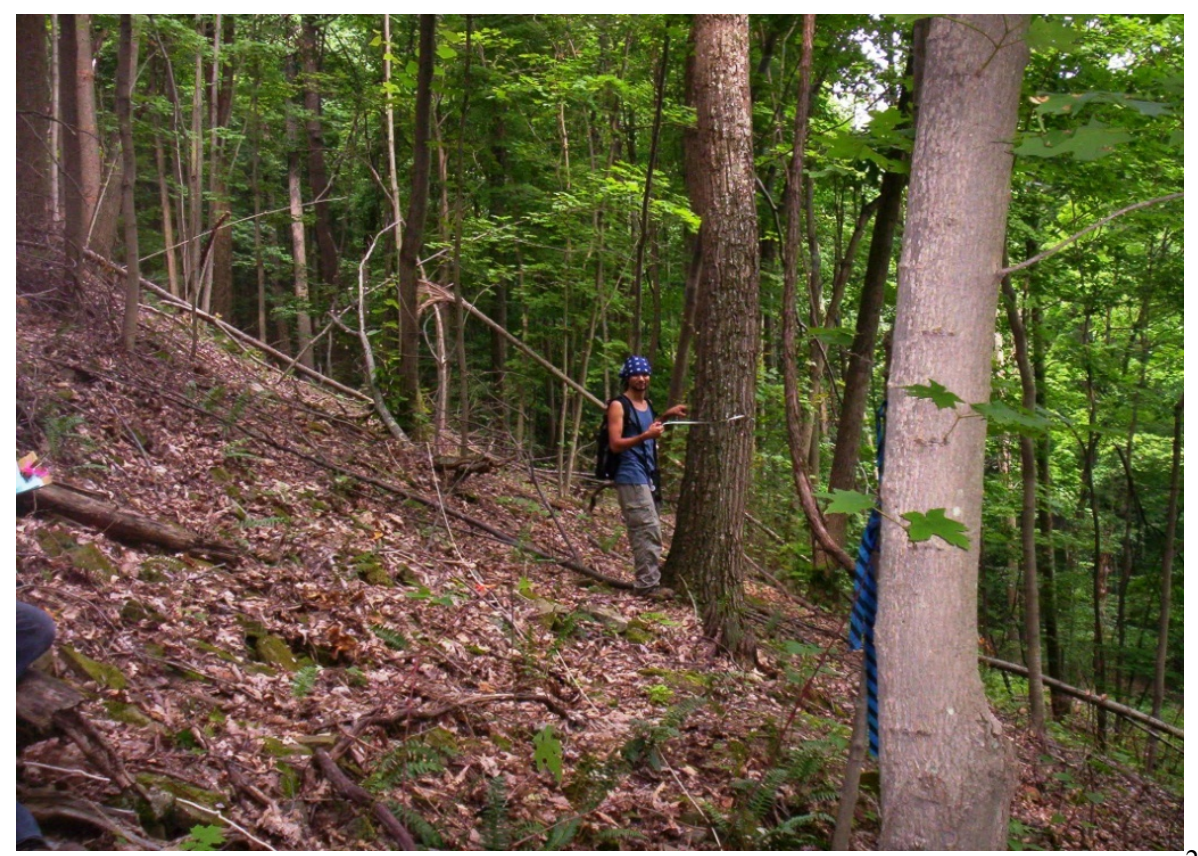

Figure 2: Light treatment harvest (residual basal area of $14.5-24.3 \mathrm{~m}^{2} / \mathrm{ha}$ ) at Lewis-Wetzel study area in West Virginia (Photo Credit: Patrick McElhone). 


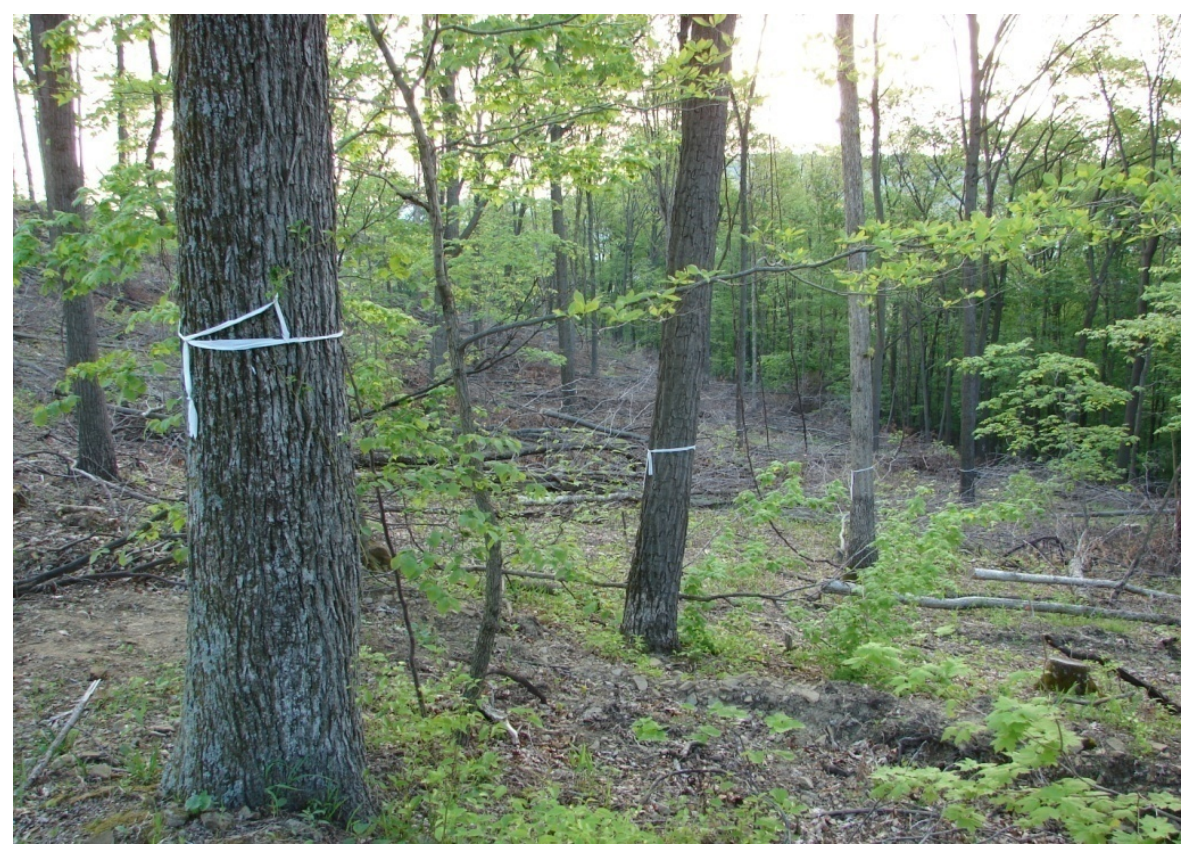

Figure 3: Intermediate treatment harvest (residual basal area of $11.5-17.1 \mathrm{~m}^{2} / \mathrm{ha}$ ) at LewisWetzel study area in West Virginia (Photo Credit: Gregory George).

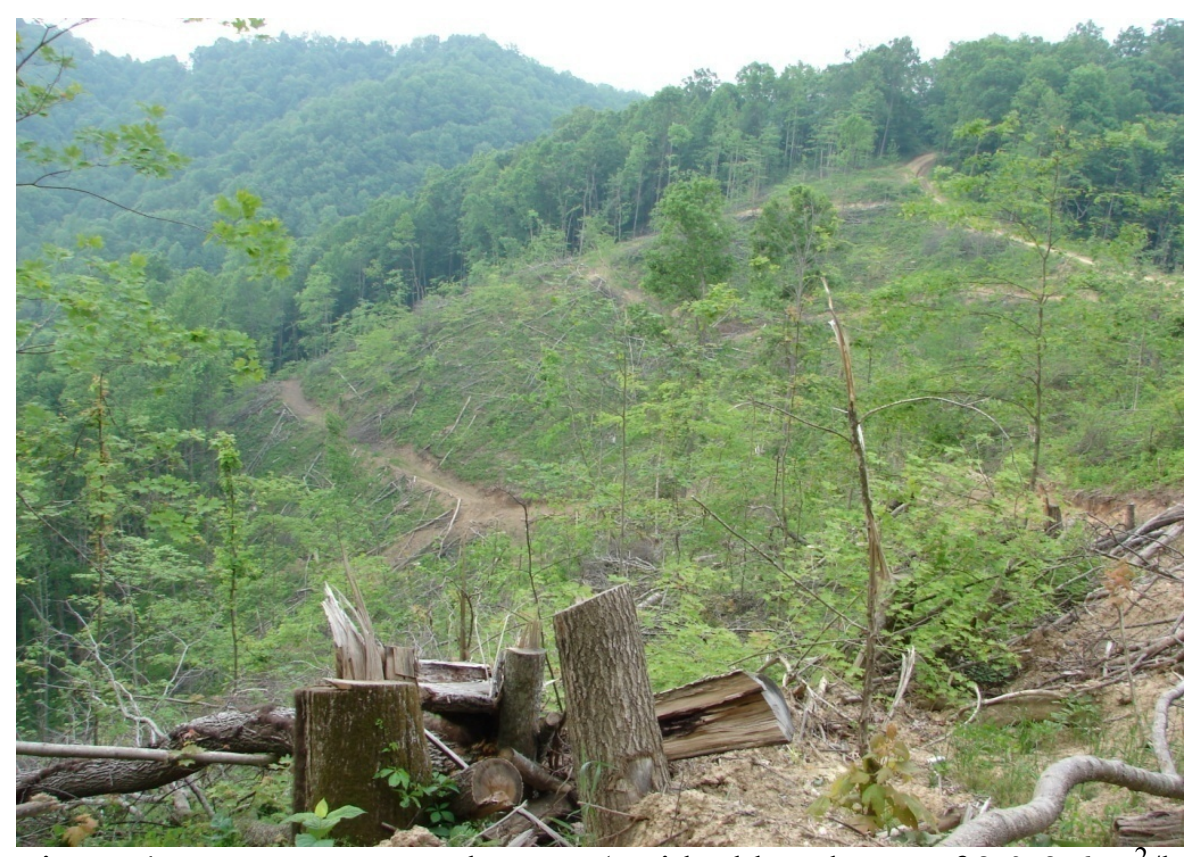

Figure 4: Heavy treatment harvest (residual basal area of $3.0-9.6 \mathrm{~m}^{2} / \mathrm{ha}$ ) at Wyoming County study area in West Virginia (Photo Credit: Gregory George). 


\section{CHAPTER 2}

Influence of silviculture on male Cerulean Warbler (Dendroica cerulean) foraging ecology and tree species selection. 
Abstract

Understanding foraging ecology provides insight into species resource requirements and overall conservation needs. We examined foraging behavior and tree species selection of male Cerulean Warblers (Dendroica cerulea), a species of conservation concern, in response to varying degrees of habitat disturbance from silvicultural treatments at four study sites in West Virginia, Kentucky and Ohio, during the 2006 and 2007 breeding seasons. During 673 foraging observations, Cerulean Warblers foraged primarily in the forest canopy, along branch tips by gleaning insects off leaf surfaces, often adjacent to canopy gaps, both pre- and post-harvest. Aerial foraging increased after harvests. Tree species availability, based on importance values (IV) calculated from density, frequency and basal areas, differed from tree species used for foraging both preand post-harvest $(\mathrm{p}<0.01)$. Preferred species included hickory (Carya spp.), sugar maple (Acer saccharum), and chestnut oak (Quercus prinus), while red oak (Quercus rubra) was strongly avoided. Tree species selection changed little post-harvest in all silvicultural treatments. Cerulean Warblers exhibited selection preferences, therefore, maintaining availability of preferred tree species is important for management of Cerulean Warbler populations.

Keywords: Cerulean Warbler, Dendroica, foraging ecology, silviculture 
Information on Cerulean Warbler (Dendroica cerulea ) foraging ecology is limited. Yet, understanding foraging behavior can provide insight into the species ecology, their resource requirements, and overall conservation needs (Petit et al. 1995, Hamel 2000). Hamel (2000) described typical foraging microhabitat locations in the canopy near dense clusters of leaves where Cerulean Warblers navigate along tree branches looking at upper and lower leaf surfaces. Gleaning insects from leaves is the primary method of food acquisition (Hamel 2000). In West Virginia, Cerulean Warblers regularly used multiple tree species for foraging or singing such as chestnut oak (Quercus prinus), red oak (Q. rubra), maples (Acer spp.), hickories (Carya spp.), and white oak (Q. alba) with nine other species, such as tulip poplar (Liriodendron tulipfera), used less frequently (Rosenberg et al. 2000). However, these data were qualitative and did not examine availability of tree species. On the periphery of the species range, Gabbe et al. (2002) investigated tree species use versus availability in southern Illinois and found Cerulean Warblers to be highly selective of hickory species while avoiding others, such as tulip poplar. Abundance of Lepidoptera larva, an important Cerulean Warbler prey item, vary by tree species (Holmes and Schultz 1988, Marshall and Cooper 2004) and microclimate characteristics (Niesenbaum and Kluger 2006); this variation could result in tree species selectivity.

Cerulean Warblers, once common, have declined at a net rate of 4.1\% per year from 1966 through 2007 (Sauer et al. 2008). Although they have recently expanded in parts of their range, the species appears to be declining primarily in the core of their breeding range (Jones et al. 2004, Sauer et al. 2008). Consequently, Cerulean Warblers are a focal species for conservation efforts (Hamel et al. 2004). Cerulean Warblers were identified by the U.S. Fish and Wildlife Service (2008) as a bird of conservation concern.

Few studies have examined response of Cerulean Warblers to silvicultural treatments (Wood et al. 2005). No studies have investigated the effects of silvicultural treatments, and the associated change in forest structure, composition, and microclimate, on Cerulean Warbler 
foraging microhabitat or behavior, yet timber harvesting is a substantial portion of the economy in the core range of the species (Childs 2005). Cerulean Warbler response to silvicultural treatments, representing varying degrees of habitat disturbance, would provide vital habitat use and conservation information. Specifically, we addressed the following objectives: 1) quantify preferences in foraging habitat and behaviors of Cerulean Warblers in their core range; 2) determine if they forage in association with forest canopy gaps; 3) determine if Cerulean Warblers forage in tree species disproportionately from availability; 4) quantify effects of timber harvesting on foraging habitat, behavior, and tree species selection of Cerulean Warblers.

\section{METHODS}

Study area.

Research was conducted in 2006 and 2007 at two study sites in West Virginia and one in Kentucky. Additionally, in 2007, data were collected at a study site in Ohio. Study sites included the Lewis Wetzel Wildlife Management Area (LWWMA) in Wetzel County, West Virginia, forested private timberlands in Wyoming County, West Virginia (Wagner), Daniel Boone National Forest (DBNF) in Bath and Menifee counties, Kentucky, and the Raccoon Ecological Management Area (REMA) in Vinton County, Ohio. All study sites are within the core of the species range (Hamel 2000). In 2006, all sites were predominately mature second growth mixed mesophytic and northern hardwood forests. Predominant tree species at LWWMA and DBNF included maple sp. (Acer spp.), oak sp. (Quercus spp.), hickory sp. (Carya spp.), and tulip poplar (Liriodendron tulipifera). Wagner and REMA were similar to LWWMA and DBNF, although maples were a less significant component. Elevation at Wagner was 400650m, while DBNF, LWWMA, and REMA were between 200-400m. All study areas were characterized by narrow valleys with steep slopes and convoluted ridges with no prevailing orientation. 
Four, 20 ha, plots were placed along ridge-tops on northern and eastern aspects at each site. Each plot was generally rectangular shaped with two 5 ha uncut buffers located on the plot ends and a central 10 ha block that received a timber harvest treatment. The treatment area was randomly assigned one of four timber harvesting treatments including an unharvested control, a light treatment similar to a single tree selection harvest, an intermediate treatment approximating a shelterwood harvest, and a heavy treatment approximating a deferment harvest. Respective residual basal area (RBA) per treatment type was $14.5-24.3 \mathrm{~m}^{2} / \mathrm{ha}, 11.5-17.1 \mathrm{~m}^{2} / \mathrm{ha}$, and 3.0 -

$9.6 \mathrm{~m}^{2} /$ ha. The treatment mosaic resulted in three, 10 ha segments receiving a timber harvest and a combined 50 ha of uncut forest at each site. Timber harvests were implemented in fall and winter of 2006. Timber selection within harvest areas were independent of tree species resulting in relative stability of tree species composition between seasons. Within the light harvest red oak group increased by $8 \%$ while chestnut oak increased by $7 \%$ within the intermediate harvest. Although most tree species had a percent change of no greater then $+/-2$ percent no other tree species had a greater then $5 \%$ change between pre- and post-harvest years.

Surveys

Each 20 ha plot was searched for foraging male Cerulean Warblers between 1 May and 15 July, 2006 and 2007. For each foraging bird located, we recorded a single point observation to avoid statistical issues associated with independence of observations (Hejl et al. 1990). When a foraging bird was first detected, the observer waited 5 seconds before recording any foraging behavior to avoid bias associated with obvious maneuvers (Hejl et al. 1990). Multiple foraging observations per individual per day were recorded with a minimum of 60 minutes between observations. The 60 minute window allows for statistical independence among observations; 1 minute windows have been considered a biologically independent timeframe for Neotropical migrants use of habitat within a territory (Barg et al. 2005). 
Data recorded for each observation were foraging maneuver, forest structure, distance from tree bole, adjacency to forest gaps, and tree species occupied. We defined two aerial foraging maneuvers and two near-perch maneuvers similar to Remsen and Robinson (1990). The aerial maneuvers were aerial hawk, the traditional flycatcher maneuver, and sally glean which was used to secure sessile prey on vegetative surfaces. The near-perch maneuvers were vegetation pick, a pick maneuver towards vegetative surfaces and woody picks directed towards branches or tree bark.

Forest structure was recorded as position within the vegetative column and was divided into under-story, mid-story and canopy. Foraging distance from the center, or bole, of the tree was divided into five, 20-percentile, categories starting from the tree bole and moving outward. The first category was the inner most $1-20 \%$ of branch length while the last category was the outermost $80-100 \%$ of the branch tips. Four categories of canopy gaps were identified: no gap, a small gap similar to a single tree fall gap or single tree removal, an intermediate gap such as a road edge or small tree group removal, or a large canopy gap that resulted in forest clearing such as a wildlife food plot or large tree group removal. A foraging observation was considered adjacent to a gap if the tree occupied was adjacent to the canopy gap.

To quantify availability of forest structure ocular tubes were used to determine presence or absence of vegetation within the understory $(0.5-3 \mathrm{~m})$, mid-story $(3 \mathrm{~m}-12 \mathrm{~m})$, and canopy $(>12 \mathrm{~m})$.

To characterize foraging habitat, behavior, and association with canopy gaps of male Cerulean Warblers, we summarized data from foraging observations across study areas and silvicultural treatment plots for each year to increase sample sizes among treatment areas. Data from all 4 study areas and all 4 treatment plots were included.

To determine whether Cerulean Warblers foraged on trees proportional to availability, we used a $2.5 \mathrm{x}$ factor metric prism to quantify tree species availability on the West Virginia and 
Kentucky plots. We recorded species of each live tree and DBH (diameter at breast height) of each tree or snag in the prism plot. Locations of prism plots were randomly selected with 20 prism plots per study plot (one per ha). Importance values (IV) were calculated from relative density, relative frequency, and relative basal areas to determine tree species preference (Holmes and Robinson 1981, Gabbe et al. 2002). Importance values were converted into importance percentages to characterize overall tree species availability to foraging individuals. Tree species with IV $\leq 2 \%$ had too few foraging observations to be included in analyses. Twelve tree species or groups (Figure 1) met the $2 \%$ IV criteria. Due to inconsistencies in identification of hickory and oak trees to species, we grouped all hickory and red oak species into their respective single categories of hickory and red oak.

To quantify forest structure availability, ocular tubes were used to determine presence or absence of vegetation within six height classes $(0.5-3 \mathrm{~m}, 3-6 \mathrm{~m}, 6-12 \mathrm{~m}, 12-18 \mathrm{~m}, 18 \mathrm{~m}-24 \mathrm{~m}$, and $>24 \mathrm{~m}$ ) centered on each prism plot. Five ocular determinations were made every $2.3 \mathrm{~m}$ in each cardinal direction, with an additional center point, totaling 21 ocular determinations within each height class. The six height classes were combined into three forest structure categories, understory $(0.5-3 \mathrm{~m})$, mid-story $(3 \mathrm{~m}-12 \mathrm{~m})$, and canopy $(>12 \mathrm{~m})$. Percent availability was based on the total number of positive ocular determinations for vegetation, out of maximum possible across all study areas, within each height class. Relative percent of forest structure availability was calculated for uncut forest, light harvest, and intermediate harvest.

It is important to view resource availability from the perspective of the forager (Hutto 1990), as much as possible. To verify that trees of all available diameters were used by Cerulean Warblers for foraging, we inspected the distributions of tree diameters at breast height (DBH) for trees available in the 2007 field season (Figure 2), which could influence the interpretation of resource availability. Based on the similarities between DBH distributions for use versus 
availability, it appears that Cerulean Warblers selected trees irrespective of their DBH, therefore, no modification of the tree availability dataset was needed prior to analysis.

To compare data pre- and post-harvest, we combined foraging observations across three study areas for analysis. The Ohio dataset was excluded because it did not contain pre-treatment data. Additionally, we excluded foraging observations from the heavy treatment plots because of the extremely small sample size. Unharvested controls and buffer areas were combined into the category, uncut forest, because of low detections in controls.

\section{Statistical Analyses}

We compared foraging variables (foraging maneuver, forest structure, distance from tree bole, adjacency to forest gaps, and tree species occupied) between pre-treatment and posttreatment seasons with the Fisher Exact test because some categories had expected values of less than five (Conover 1999). We used paired chi-square tests to discern which foraging categories were different from pre- to post- harvest with $\alpha=0.01$ for significance to be more conservative while performing multiple tests.

To quantify tree species selection, we compared observed foraging frequencies to expected frequencies (Holmes and Robinson 1981, Gabbe et al. 2002) using a chi-square goodness-of-fit test with Monte Carlo estimates of exact $p$ values for probability. Importance values, calculated for each tree species, were multiplied by the total number of observations to obtain the expected frequencies. Preference indices, deviation of observed versus expected values, are used to depict tree species preference or avoidance. We completed a separate analysis for each treatment type (i.e. light harvest, intermediate harvest, and uncut forest) and year.

All analyses were computed within the R statistical language ( $\mathrm{R}$ Development Core Team, 2007). We set $\alpha=0.05$ for significance for all tests except paired chi-square tests. 
Results

General Foraging Behavior and Habitat

We collected 673 foraging observations of male Cerulean Warblers from four study sites (Table 1). During the 2006 pre-treatment season, they used vegetation picks most often (73.3\%) followed by wood-pick (19.3\%), sally-glean $(6.8 \%)$, and aerial hawk $(<1 \%)$. For the posttreatment season the pattern was similar $(65.4 \%, 12.2 \%, 17.7 \%$ and $4.7 \%$ respectively).

During both the 2006 and 2007 breeding seasons, the majority of Cerulean Warbler observations were in the forest canopy (74.7\% and $86.2 \%$ respectively). The mid-story had $24.0 \%$ and $13.0 \%$ of foraging detections, respectively, while the understory only accounted for $1.3 \%$ and $0.8 \%$ of foraging maneuvers in each year. Variation in percent forest structure availability between pre- and post-harvest was minimal (Table 2). In the light harvest, percent change of understory, mid-story, and canopy was $-3.3 \%, 2.1 \%$, and $1.2 \%$ respectively and $0.7 \%$, 0.3 , and $-1.0 \%$ respectively for the intermediate harvest.

For distance from bole, the majority of observations were in the outer two distance categories accounting for $26.0 \%$ and $42.3 \%$ of observations during the pre-treatment year. Posttreatment was similar, $25.8 \%$ and $35.5 \%$ respectively.

Cerulean Warblers foraged away from canopy gaps during the pre-treatment year $33.4 \%$ of the time, but gaps of some form were used on a regular basis $(66.6 \%)$. Specifically, small gaps were used the most (33.1\%) followed by intermediate $(25.9 \%)$ then large gaps $(7.5 \%)$. During the post-treatment year, Cerulean Warblers spent the least amount of time foraging away from canopy gaps (19.0\%), small gaps were used $24.1 \%$, with intermediate and large gaps being used $31.3 \%$ and $25.6 \%$ respectively.

Silvicultural Influences on Foraging Behavior and Habitat 
Use of foraging maneuvers differed pre- and post-treatment in both harvests but not in uncut forests (Table 3). Cerulean Warblers increased their use of aerial foraging maneuvers (sally-glean and aerial hawk) by a magnitude of three or more in the light and intermediate harvests post-treatment.

Forest structure use in uncut forested areas and the intermediate harvest had a significant decrease in mid-story use between years. No significant change occurred in the light harvest (Table 3).

Cerulean Warblers generally shifted their foraging away from branch tips towards a more moderate distance away from the tree bole in the light and intermediate harvests, although the latter was not statistically significant (Table 3). No significant change occurred in the uncut forested areas (Table 3).

Canopy gaps were important for foraging Cerulean Warblers and use changed pre- and post-treatment in both harvests (Table 3). Between years, in the light harvest, we had an overall decrease in foraging associated with no gap and small gap categories while a ten-fold increase was associated with intermediate gaps and foraging associated with large gaps doubled. In the intermediate harvest, foraging use of all gaps decreased, while use of large gaps had a ten-fold increase (Table 3).

\section{Tree Species Selection}

Although only twelve tree species occurred frequently enough to be included in analyses of tree species preference, Cerulean Warblers foraged in 23 different tree species or groups. Across all treatments and study areas, Cerulean Warblers selected tree species disproportionate to availability for both pre-treatment and post-treatment seasons $(\mathrm{p}<0.01$ for each season). During both field seasons, they preferred chestnut oak, the hickory group, and sugar maple while 
avoiding the red oak group (Figure 1). The remaining 8 tree species, while trending towards slight avoidance, were used relatively proportional to availability.

Comparing pre- and post-harvest years for each harvest treatment, Cerulean Warblers selected tree species disproportionate to availability across all treatment types (Table 4). We generally found positive preference index scores, of varying degrees, for chestnut oak, hickory group, and sugar maple, while red oaks were avoided. Tree species selection was consistent across harvests types indicating overall lack of harvest specific influence.

Overall change in tree species availability, within the harvest areas, was low between seasons (Table 5). Only one tree species per harvest type changed $>5 \%$. The red oak group increased $8 \%$ in the light harvest and chestnut oak increased $7 \%$ in the intermediate harvest.

\section{Discussion}

Foraging Behavior

Male Cerulean Warblers primarily foraged in the forest canopy out along branch tips by gleaning insects off leaf surfaces as similarly described by Hamel (2000). Vegetation structure influences how foragers search for, and secure, prey items (Robinson and Holmes 1982) irrespective of efficiency (Stephens and Krebs 1986). The increased use of aerial maneuvers was only associated with the harvested areas. The silvicultural treatments resulted in a more open forest which can result in increased abundance and activity of flying insects (Gorham et al. 2002, Smith and Dallman 1996, Blake and Hoppes 1986). Although flying insects are not the preferred Cerulean Warbler food source (Hamel 2000), the increased space might allow aerial maneuvers to be more plausible, specifically from a spatial perspective.

Foraging theory provides a framework within which to ask questions about foraging behavior and suggests that individuals will respond in a way that will result in a net increase in their reproductive fitness (Stephens and Krebs 1986). The two major decisions a forager has to 
make are what prey items to select and at what moment to leave a foraging location, a patch, and travel to a new patch. The forager tries to balance these two decisions and yield the highest net energy gain.

Aerial maneuvers are more energy expensive than near-perch maneuvers and potentially expose the individual to increased predation by making itself more obvious. Considering that the Cerulean Warbler is evolutionarily predisposed to be an efficient near-perch gleaner, morphologically and behaviorally (Cody 1985), the shift in maneuver selection towards aerial maneuvers within the forest treatments might be the outward expression of decreased foraging efficiency within treatment areas compared to individuals foraging within the uncut forest areas. In a study on energy budgets in Dark-eyed Junco (Junco hyemalis), birds experiencing a negative energy budget were likely to engage in more risk prone behavior (Caraco 1981). Additionally, birds have been found to exhibit risk prone behavior when in need to increase mass (Bednekoff and Houston 1994).

\section{Association with Canopy Gaps}

Cerulean Warblers regularly foraged in close proximity to canopy gaps. Vertical complexity in forest structure is known to be important to the Cerulean Warbler (Lynch 1981, Hunter et al. 2001, Perkins 2006). The increased amount of sunlight in forest gaps results in a more vertically diverse forest structure, either by increased sapling growth or epicormic branching from large trees. Increased diversity of forest structure would be associated more to older canopy gaps that were available during the pre-harvest year, then the harvest related, canopy gaps due to lack of time for harvest response. In addition to foraging, nest site selection (Oliarnyk and Robertson 1996) and placement of territories (Perkins 2006) are often adjacent to canopy gaps. Canopy gaps specifically related to silvicultural activities are used routinely by Cerulean Warblers. Selective harvests in North Carolina (Lynch 1981), two-aged stands in West 
Virginia (Nichols 1996), and clearcut stands, 16 years post-harvest, (Wood et al. 2005) each contained Cerulean Warbler populations. Canopy gaps, regardless of disturbance source, appear to be an important component of Cerulean Warbler habitat.

The use of canopy gaps was potentially related to resource availability. Increased primary productivity associated with increased light levels found in canopy gaps might result in increased food availability (Fogden 1972) in the form of Lepidoptera larva. Lepidoptera are the most common and diverse group of invertebrates in eastern deciduous forests (Hammond and Miller 1998, Summerville et al. 1999) and represent an important food source for Cerulean Warblers (Hamel 2000). Additionally, the warmer microclimate associated with increased light levels could result in increased abundance and activity of flying insects (Blake and Hoppes 1986, Smith and Dallman 1996, Gorham et al. 2002) which could help explain the increased use of aerial foraging maneuvers post-harvest when there were more canopy gaps. Nitrogen is known to be an important limiting factor in growth of invertebrate herbivores (Mattson 1980; Scriber and Slansky 1981, Mattson et al. 1991, Fortin and Mauffette 2002). Increased light levels are correlated with increased levels of nitrogen within leaves (Hemming and Lindroth 1995, Fortin and Mauffette 2002) potentially resulting in an increase in food availability for foraging birds. However, Kilgo (2005) found a decrease in foliage-dwelling arthropod abundance from forest edge to interior forest, defined as $>100 \mathrm{~m}$ from the edge, and concluded that Hooded Warblers (Wilsonia citrine) encountered less prey, and therefore foraged less proficiently, lower attack rate, near gaps. Different silvicultural treatments influence invertebrate distributions, the major food source for Neotropical migratory birds (Summerville and Crist 2002, Duguay et al. 2000). Heavy harvests had reduced invertebrate species richness (Summerville and Crist 2002) and biomass (Duguay et al. 2000). Summerville and Crist (2002) found no difference in species richness between selectively logged and unlogged stands. 
Cerulean Warblers increased their foraging activities adjacent to canopy gaps posttreatment, although this increase was only associated with treatment areas while canopy gap use in uncut forested buffers remained unchanged. Additionally, an overall increase in territory density was observed within treatment areas (unpublished data).

\section{Tree Species Selection}

Within the core range of Cerulean Warblers, we observed strong selection of some tree species while others were avoided. Therefore, maintaining availability of preferred tree species, such as hickories, sugar maple, and chestnut oak, may be important for the management of Cerulean Warbler populations. Trends of tree species preference were relatively consistent across silvicultural treatment types in our study. This suggests that some other component, perhaps variability in Lepidoptera larva, might be the catalyst for tree species preferences (Holmes and Schultz 1988).

Red oaks were strongly avoided across treatments and years. This could be due to relatively high tannin levels in red oak leaves (Wood 2005). Additionally, in northern Japan, increase $\mathrm{d}$ tannin levels among tree species resulted in reduced Lepidoptera larva biomass (Murakami 1998). Some Lepidoptera larva species are known to have difficulty digesting leaves with higher tannin levels which results in poor growth, and therefore, reduced overall biomass of larva (Karowe 1989).

Marshall and Cooper (2004) determined that abundance of Lepidoptera larva varied during the breeding season within and among tree species. Highest densities of larva were found in the pre-nesting season with lower densities during the breeding season. Marshall and Cooper (2004) found that red oak had comparable Lepidoptera larva abundance to maples, hickories, white oak, and chestnut oak (about 30 caterpillars/ kg leaf biomass). Because red oaks were 
avoided for foraging in our study, this suggests other factors, such as tannin levels, influenced tree species preferences.

\section{Conservation Implications}

These results have two implications of particular importance for the conservation of Cerulean Warblers. First, Cerulean Warbler association with canopy gaps is well established (Oliarnyk and Robinson 1996, Hamel 2000, Perkins 2006). A mature forest naturally develops small canopy gaps in various ways (tree mortality, wind throw, ice storms) creating the diverse forest structure deemed important to Cerulean Warblers. Within the central Appalachian Mountains, forest canopy disturbance is often created through timber management. Wildlife managers have the ability to mimic the natural environment by prescribing low intensity timber harvest to promote the diverse forest structure associated with Cerulean Warbler foraging habitat.

Second, attention should be placed not only on forest structure but also on the resulting tree species composition produced by timber management. Specifically, for Cerulean Warblers, promote retention of sugar maples in the forest canopy. Silvicultural activities implemented to manage Cerulean Warbler populations can maintain availability of preferred tree species for foraging while promoting overall tree species diversity.

\section{Acknowledgements}

Funding for this work was provided by the National Fish and Wildlife Foundation, National Council for Air and Stream Improvement, U.S. Fish and Wildlife Service, West Virginia Division of Natural Resources, Kentucky Department of Fish and Wildlife Resources, Ohio Department of Natural Resources, and U.S. Forest Service Monongahela National Forest. We thank P. McElhone, P. White, V. Lane, and numerous field technicians for assistance in data 
collection. We also thank S. Durham and L. Skrzypek for logistical support. We thank the West Virginia Division of Natural Resources, Advantage Timberland, Forest Land Group and Wagner LTD for allowing us access to their properties and implementing timber harvests. Use of trade names does not imply endorsement by the Federal government.

\section{Literature Cited}

Barg, J. B., J. Jones, and R. J. Robertson. 2005. Describing breeding territories of migratory passerines: suggestions for sampling, choice of estimator, and delineation of core areas. Journal of Animal Ecology 74:139-149.

Bednekoff, P. A. and A. I. Houston. 1994. Dynamic models of mass-dependent predation, risksensitive foraging, and premigratory fattening in birds. Ecology 75:1131-1140.

Blake, J. G., and W. G. Hoppes. 1986. Influence of resource abundance on use of tree-fall gaps by birds in an isolated woodlot. Auk 103: 328-340.

Caraco, T. 1981. Energy budgets, risk and foraging preferences in dark-eyed juncos (Junco hyemalis). Behav. Ecol. Sociobiol. 8:213-217.

Childs, R. A. 2005. West Virginia's Forests: Growing West Virginia'sFuture. Bureau of Business and Economic Research, College of Business and Economics, West Virginia University. Pp 1-14.

Cody, M. L. 1985. Habitat selection in birds. Academic Press, San Diego, CA

Conover, W.J. 1999. Practical nonparametric statistics. Wiley series in probability and statistics: Applied probability and statistics section. John Wiley \& Sons, New York, New York.

Duguay, J. P., P. B. Wood, and G. W. Miller. 2000. Effects of timber harvest on invertebrate biomass and avian nest success. Wildlife Society Bulletin 28:1123-1131.

Fogden, M. P. L. 1972. The seasonality and population of equatorial forest birds in Sarawak. Ibis 114:307-342.

Fortin, M. and Y. Mauffette. 2002. The suitability of leaves from different canopy layers for a generalist herbivore (Lepidoptera: Lasiocampidae) foraging on sugar maple. Canadian Journal Forest Research. 32:379-389.

Gabbe, A. P., S. K. Robinson,, and J. D. Brawn. 2002. Tree-species preferences of foraging Insectivorous Birds: Implications for floodplain forest restoration. Conservation Biology $16: 462-470$. 
Gorham, L. E., S. L. King, B. D. Keeland, and S. Mopper. 2002. Effects of canopy gaps and flooding on homopterans in a bottomland hardwood forest. Wetlands 22:541-549.

Hamel, P. B. 2000. Cerulean Warbler (Dendroica cerulea). In The Birds of North America, No. 511 (A. Poole and F. Gill, editors). The Birds of North America, Inc., Philadelphia, Pennsylvania.

Hamel, P. B., D. K. Dawson, and P. D. Keyser. 2004. How can we learn more about the Cerulean Warbler (Dendroica cerulea). Auk 121:7-14.

Hammond P. C., and J. C. Miller. 1998. Comparison of the biodiversity of Lepidoptera within three forested ecosystems. Annals of the Entomological Society of America 91:323-328

Hej1, S. J., J. Verner, and G. W. Bell. 1990. Sequential versus initial observation in studies of avian foraging. Pp 166-173 in (M. Morrison, C. Ralph, J. Verner, and J. Jehl, Jr. eds.) Studies in avian biology No:13. Avian foraging: Theory, methodology and application. Cooper Ornithological Society.

Hemming, J. D. C., and R. L. Lindroth. 1995. Intraspecific variation in aspen phytochemistry: effects on performance of gypsy moths and forest tent caterpillars. Oecologia 103: 79-88.

Holmes, R. T. and S. K. Robinson. 1981. Tree species preference of foraging insectivorous birds in a northern hardwood forest. Oecologia 48:31-35.

Holmes, R. T. and J. C. Schultz. 1988. Food availability for forest birds: effects of prey distribution and abundance on bird foraging. Canadian Journal Zoology. 66:720-728.

Hunter, W. C., D. A. Buehler, R. A. Canterbury, J. L. Confer, and P. B. Hamel. 2001. Conservation of disturbance-dependent birds in eastern North America. Wildlife Society Bulletin 29:440-455.

Hutto, R. L., 1990. Measuring the availability of food resources. Pp 20-28 in (M. Morrison, C. Ralph, J. Verner, and J. Jehl, Jr. eds.) Studies in avian biology No:13. Avian foraging: Theory, methodology and application. Cooper Ornithological Society.

Jones, J., J. J. Barg, T. S. Sillett, M. L. Veit, and R. J. Robertson. 2004. Minimum estimates of survival and population growth for Cerulean Warblers (Dendroica cerulea) Breeding in Ontario, Canada. Auk 121:15-22.

Karowe, D. N. 1989. Differential effect of tannic acid on two tree-feeding Lepidoptera: implications for theories of plant anti-herbivore chemistry. Oecologia 80:50-512.

Kilgo, J. C. 2005. Harvest-related edge effects on prey availability and foraging of hooded warbler in a bottomland hardwood forest. Condor 107:627-636.

Lynch, J. M. 1981. Status of the Cerulean Warbler in the Roanoke River basin of North Carolina. Chat 45:29-35.

Marshall, M. R. and R. J. Cooper. 2004. Territory size of a migratory songbird in response to caterpillar density and foliage structure. Ecology 85:432-445. 
Mattson W. J. JR. 1980. Herbivory in relation to plant nitrogen content. Annual Reviews in Ecology and Systematics 11:119-161.

Mattson, W.J., R.A. Haack, R. K. Lawrence and S. S. Slocum. 1991. Considering the nutritional ecology of the spruce budworm in its management. Forest Ecology and Management. 39:183-210.

Murakami, M. 1998. Foraging habitat shift in the narcissus flycatcher, Ficedula narcissina, due to the response of herbivorous insects to the strengthening defenses of canopy trees. Ecological Research 13:73-82.

Nichols, J. V. 1996. Effects of two-age timber management and clearcutting on songbird density and reproductive success. MS thesis. West Virginia University, Morgantown.

Niesenbaum, R. A., and E. C. Kluger. 2006. When Studying the Effects of Light on Herbivory, Should One Consider Temperature? The Case of Epimecis hortaria F. (Lepidoptera: Geometridae) Feeding on Lindera benzoin L. (Lauraceae). Environmental Entomology. 35: 600-606.

Oliarnyk, C. J., and R. K. Robertson. 1996. Breeding behavior and reproductive success of Cerulean Warblers in southeastern Ontario. Wilson Bulletin. 108:673-684.

Perkins, K. A. (2006). Cerulean Warbler Selection of Forest Canopy Gaps. Master's Thesis, West Virginia University.

Petit, D. R., J. F. Lynch, R. Hutto, J. G. Blake, and R. B. Waide. 1995. Habitat Use and Conservation in the Neotropics. Pp. 145-197 in (T. Martin and D.Finch, eds.). Ecology and Management of Neotropical Migratory Birds: A Synthesis and Review of Critical Issues.. Oxford University Press, New York, NY.

R Development Core Team (2007). R: A language and environment for statistical computing. R Foundation for Statistical Computing, Vienna, Austria. ISBN 3-900051-07-0, URL http://www.R-project.org.

Remsen, J. V., JR. and S. K. Robinson. 1990. A classification scheme for foraging behavior of birds in terrestrial habitats. Pp 144-160 in (M. Morrison, C. Ralph, J. Verner, and J. Jehl, Jr. eds.) Studies in avian biology No:13. Avian foraging: Theory, methodology and application. Cooper Ornithological Society.

Robinson, S. K., and R. T. Holmes. 1982. Foraging behavior of forest birds: The relationships among search tactics, diet, and habitat structure. Ecology 63:1918-1931.

Rosenberg, K. V., S. E. Barker, and R. W. Rohrbaugh. 2000. An atlas of Cerulean Warbler populations. Final report to USFWS: 1997-2000 breeding seasons. Cornell Lab of Ornithology, Ithaca, NY.

Scriber, J.M., and F. Slansky, Jr. 1981. The nutritional ecology of immature insects. Annual. Review of Entomology. 26:183-211. 
Sauer, J. R., J. E. Hines, and J. Fallon. 2008. The North American Breeding Bird Survey, Results and Analysis 1966-1999. Version 5.15.2008, USGS Patuxent Wildlife Research Center, Laurel, Md.

Smith, R. and M. Dallman. 1996. Forest gap use by breeding Black-throated Green Warblers. Wilson Bulletin 108:588-591.

Stephens, D. W. and J. R. Krebs 1986. Foraging theory. Princeton University Press, Princeton, New Jersey.

Summerville, K. S., J. J. Jacquot, and R. F. Stander. 1999. Preliminary checklist of the moths of Butler County, Ohio. Ohio Journal of Science 99:66-76.

Summerville, K. S. and T. O. Crist. 2002. Effects of timber harvest on forest Lepidoptera: community, guild, and species response. Ecological Applications 12:820-835.

U.S. Fish and Wildlife Service. 2008. Birds of conservation concern 2008. United States Department of Interior, Fish and Wildlife Service, Division of Migratory Bird Management, Arlington, Virginia. 85pp. [Online version available at http://www.fws.gov/migratorybirds/>]

Wood, M. D. 2005. Tannin and lipid content of acorns in scatterhoards and larderhoards. Northeastern Naturalist 12:463-472.

Wood, P. B., J. P. Dugauy, and J. V. Nichols. 2005. Cerulean Warbler use of regenerated clearcut and two-age harvests. Wildlife Society Bulletin 33:851-858. 
Table 1: Total number of observations by study site and year for the pre- (2006) and posttreatment (2007) seasons. One year of data was collected at the Ohio site, REMA, during the 2007, post-treatment, season.

\begin{tabular}{lrrr}
\hline \multicolumn{1}{c}{ Study Site } & Pre & Post & Total \\
\hline Daniel Boone National Forest, KY (DBNF) & 76 & 82 & 158 \\
Lewis Wetzel Wildlife Management Area, WV (LWWMA) & 101 & 159 & 260 \\
Wyoming County, WV (Wagner) & 135 & 75 & 210 \\
Vinton County, OH (REMA) & - & 45 & 45 \\
Total & 312 & 361 & 673 \\
\hline
\end{tabular}


Table 2: Percent availability of forest structure was proportionately similar between years. Data from two West Virginia and the Kentucky study areas combined.

\begin{tabular}{|c|c|c|c|c|c|c|}
\hline & \multicolumn{2}{|c|}{$\begin{array}{l}\text { Uncut } \\
\text { Forest }\end{array}$} & \multicolumn{2}{|c|}{$\begin{array}{c}\text { Light } \\
\text { Harvest }\end{array}$} & \multicolumn{2}{|c|}{$\begin{array}{c}\text { Intermediate } \\
\text { Harvest }\end{array}$} \\
\hline & Pre & Post & Pre & Post & Pre & Post \\
\hline \multicolumn{7}{|c|}{ Forest Structure } \\
\hline Understory & 26.0 & 23.2 & 23.7 & 20.4 & 24.0 & 24.7 \\
\hline Mid-story & 37.3 & 32.2 & 36.8 & 38.9 & 32.9 & 33.2 \\
\hline Canopy & 36.7 & 44.7 & 39.6 & 40.8 & 43.1 & 42.1 \\
\hline
\end{tabular}


Table 3: Comparison of foraging variables within uncut forest, light harvest, and intermediate harvest treatments combining the Daniel Boone National Forest, Lewis-Wetzel Wildlife Management Area, and Wagner study sites for the pre- (2006) and post-treatment (2007) seasons. Included are Fisher's exact tests comparing pre- and post-treatment years to discern difference between years by harvest type. Paired chi-square tests were used to discern which foraging categories were different from pre- to post- harvest with $\alpha=0.01$ for significance. Significant results denoted by asterisk.

\begin{tabular}{|c|c|c|c|c|c|c|c|c|c|c|c|c|}
\hline & \multicolumn{4}{|c|}{ Uncut Forest } & \multicolumn{4}{|c|}{ Light Harvest } & \multicolumn{4}{|c|}{ Intermediate Harvest } \\
\hline & \multicolumn{2}{|c|}{ Pre } & \multicolumn{2}{|c|}{ Post } & \multicolumn{2}{|c|}{ Pre } & \multicolumn{2}{|c|}{ Post } & \multicolumn{2}{|c|}{ Pre } & \multicolumn{2}{|c|}{ Post } \\
\hline & $\mathrm{n}$ & $\%$ & $\mathrm{n}$ & $\%$ & $\mathrm{n}$ & $\%$ & $\mathrm{n}$ & $\%$ & $\mathrm{n}$ & $\%$ & $\mathrm{n}$ & $\%$ \\
\hline \multicolumn{13}{|l|}{ Foraging Maneuvers } \\
\hline Vegatation Pick & 106 & 71.6 & 91 & 69.5 & 50 & 66.7 & 62 & 58.5 & 62 & 82.7 & 51 & 72.9 \\
\hline Wood-Pick & 32 & 21.6 & 22 & 16.8 & 17 & 22.7 & 9 & 8.5 & 9 & 12.0 & 4 & 5.7 \\
\hline Sally-glean & 9 & 6.1 & 15 & 11.5 & 7 & 9.3 & 29 & $27.4^{*}$ & 4 & 5.3 & 11 & 15.7 \\
\hline Aerial Hawk & 1 & 0.7 & 3 & 2.3 & 1 & 1.3 & 6 & 5.7 & 0 & 0.0 & 4 & 5.7 \\
\hline Fisher's Exact Test & \multicolumn{4}{|c|}{$\mathrm{P}=0.24$} & \multicolumn{4}{|c|}{$\mathrm{P}<0.01$} & \multicolumn{4}{|c|}{$\mathrm{P}=0.01$} \\
\hline
\end{tabular}

Forest Structure

\begin{tabular}{lrrrrrrrrrrrr} 
Understory & 2 & 1.3 & 1 & 0.8 & 2 & 2.6 & 1 & 1.0 & 0 & 0.0 & 0 & 0.0 \\
Mid-story & 35 & 23.5 & 16 & $12.2^{*}$ & 20 & 26.7 & 22 & 20.8 & 18 & 24.0 & 7 & 10.0 \\
Canopy & 112 & 75.2 & 114 & $87.0^{*}$ & 53 & 70.7 & 83 & 78.3 & 57 & 76.0 & 63 & 90.0 \\
Fisher's Exact Test & \multicolumn{3}{c}{$\mathrm{P}<0.01$} & $\mathrm{P}=0.27$ & & \multicolumn{3}{c}{$\mathrm{P}=0.02$} & \\
\hline
\end{tabular}

Distance From Bole

\begin{tabular}{lrrrrrrrrrrrr}
$1-20 \%$ & 8 & 5.4 & 3 & 2.3 & 0 & 0.0 & 3 & 2.8 & 2 & 2.7 & 3 & 4.3 \\
$21-40 \%$ & 22 & 14.8 & 12 & 9.2 & 9 & 12.0 & 10 & 9.4 & 10 & 13.3 & 8 & 11.4 \\
$41-60 \%$ & 27 & 18.1 & 34 & 26.0 & 7 & 9.3 & 27 & $25.5 *$ & 11 & 14.7 & 13 & 18.6 \\
$61-80 \%$ & 44 & 29.5 & 35 & 26.7 & 23 & 30.7 & 28 & 26.4 & 10 & 13.3 & 19 & 27.1 \\
$81-100 \%$ & 48 & 32.2 & 47 & 35.9 & 36 & 48.0 & 38 & 35.8 & 42 & 56.0 & 27 & 38.6 \\
Fisher's Exact Test & \multicolumn{1}{c}{$\mathrm{P}=0.57$} & \multicolumn{1}{c}{$\mathrm{P}=0.02$} & & & $\mathrm{P}=0.09$ & \\
\hline
\end{tabular}

Gap Adjacency

\begin{tabular}{lrrrrrrrrrrrr} 
No Gap & 56 & 40.0 & 55 & 42.0 & 18 & 25.0 & 5 & $4.7^{*}$ & 22 & 30.6 & 0 & $0.0^{*}$ \\
Small Gap & 43 & 30.7 & 46 & 35.1 & 44 & 61.1 & 28 & $26.4^{*}$ & 7 & 9.7 & 2 & 2.9 \\
Intermediate Gap & 31 & 22.1 & 20 & 15.3 & 4 & 5.6 & 56 & $52.8^{*}$ & 39 & 54.2 & 22 & $31.4^{*}$ \\
Large Gap & 10 & 7.1 & 10 & 7.6 & 6 & 8.3 & 17 & 16.0 & 4 & 5.6 & 46 & $65.7^{*}$ \\
$\quad$ Fisher's Exact Test & \multicolumn{8}{c}{$\mathrm{P}=0.54$} & \multicolumn{7}{c}{$\mathrm{P}<0.01$} & & & $\mathrm{P}<0.01$ & \\
\hline
\end{tabular}


Table 4: Cerulean Warbler tree species preference and avoidance values for uncut forests, light harvest, and intermediate harvests combining the West Virginia and Kentucky study areas for pre- (2006) and post-treatment (2007). Preference and avoidance are indicated by positive and negative values, respectively. Observed versus expected values were compared with chi-square goodness-of-fit test with Monte Carlo estimates for p-values.

\begin{tabular}{|c|c|c|c|c|c|c|}
\hline \multirow[b]{2}{*}{ Tree Species } & \multicolumn{2}{|c|}{ Uncut Forest } & \multicolumn{2}{|c|}{ Light Harvest } & \multicolumn{2}{|c|}{$\begin{array}{c}\text { Intermediate } \\
\text { Harvest }\end{array}$} \\
\hline & Pre & Post & Pre & Post & Pre & Post \\
\hline American Beech & -3.97 & 0.07 & -0.23 & -0.54 & -2.85 & -2.11 \\
\hline Basswood & -0.77 & -4.55 & 1.63 & -1.04 & -1.08 & -1.14 \\
\hline Black Gum & -0.65 & -1.00 & 0.16 & -1.61 & -1.12 & -0.91 \\
\hline Chestnut Oak & 6.72 & 0.44 & -0.09 & 21.33 & 5.01 & 4.36 \\
\hline Cucumber Magnolia & -2.12 & -0.36 & -2.79 & 1.30 & -2.66 & -1.34 \\
\hline Hickory Group $^{a}$ & -0.01 & 0.49 & 9.82 & 2.42 & 8.82 & 5.72 \\
\hline Red Maple & -7.02 & -7.07 & -4.11 & 2.39 & 7.52 & 3.62 \\
\hline Red Oak Group $^{a}$ & -3.58 & -5.43 & -3.57 & -15.15 & -3.62 & -7.48 \\
\hline Sugar Maple & 18.42 & 22.83 & 7.21 & 6.06 & -3.73 & 3.60 \\
\hline Tulip Poplar & 7.02 & 6.84 & 4.43 & -7.67 & -3.51 & -1.64 \\
\hline White Ash & -1.91 & -3.62 & -2.58 & -0.42 & -2.91 & 0.17 \\
\hline White Oak & -1.59 & 4.25 & -1.70 & -0.73 & 3.05 & 6.01 \\
\hline $\mathrm{n}=$ & 143 & 135 & 75 & 106 & 75 & 70 \\
\hline$\chi^{2}=$ & 41.7 & 44.0 & 28.8 & 84.4 & 42.1 & 24.9 \\
\hline $\mathrm{P}=$ & $<0.01$ & $<0.01$ & $<0.01$ & $<0.01$ & $<0.01$ & 0.02 \\
\hline
\end{tabular}

${ }^{a}$ Hickory and red oak categories are comprised of all members of their respective groups due to inconsistency in tree species identification. 
Table 5: Tree species availability, based on Importance Values (IV), was generally similar between years within the light and intermediate harvest, represented here by percent change between years. Data from three study areas in West Virginia and Kentucky combined.

\begin{tabular}{|c|c|c|}
\hline \multirow[b]{2}{*}{ Tree Species } & \multicolumn{2}{|c|}{ IV Change (\%) } \\
\hline & Light & Intermediate \\
\hline American Beech & -0.3 & 0.9 \\
\hline Basswood & -0.1 & 1.2 \\
\hline Black Gum & -1.0 & -0.8 \\
\hline Chestnut Oak & -2.8 & 7.2 \\
\hline Cucumber Magnolia & 0.3 & 1.6 \\
\hline Hickory Group ${ }^{a}$ & 3.2 & 1.6 \\
\hline Red Maple & -2.9 & 3.6 \\
\hline Red Oak Group $^{a}$ & 8.1 & -2.7 \\
\hline Sugar Maple & -1.1 & -2.6 \\
\hline Tulip Poplar & 1.3 & -4.1 \\
\hline White Ash & -4.8 & -2.9 \\
\hline White Oak & -3.2 & -0.9 \\
\hline
\end{tabular}

${ }^{\mathrm{a}}$ Hickory and red oak categories are comprised of all members of their respective groups due to inconsistency in tree species identification. 


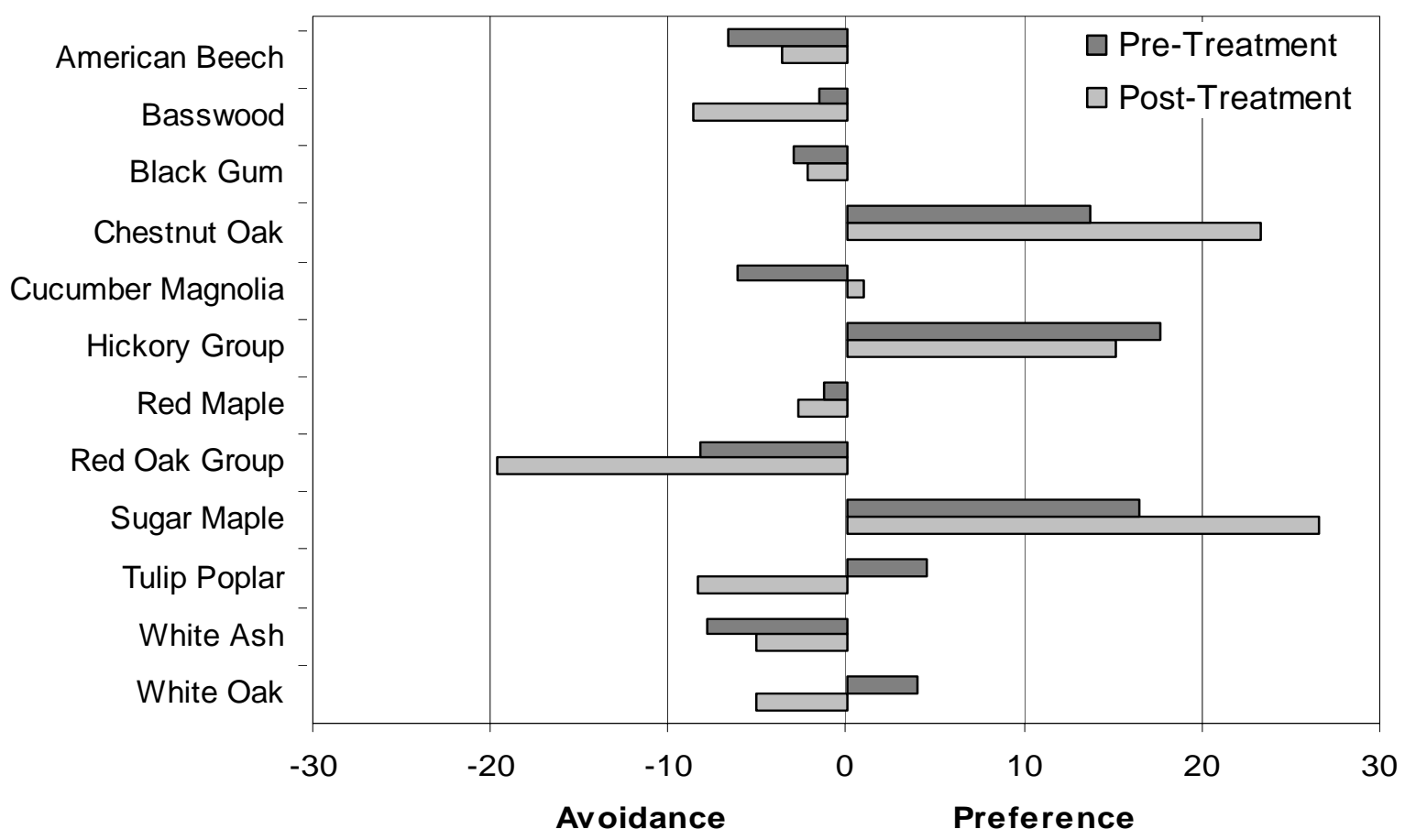

Figure 1: Pre-treatment $(2006, \mathrm{n}=312)$ and post-treatment $(2007, \mathrm{n}=316)$ indices of tree species selection and avoidance for the 12 most available tree species. Indices based on West Virginia and Kentucky study areas combined. Hickory and red oak categories are comprised of all members of their respective groups due to inconsistencies in tree species identification. 


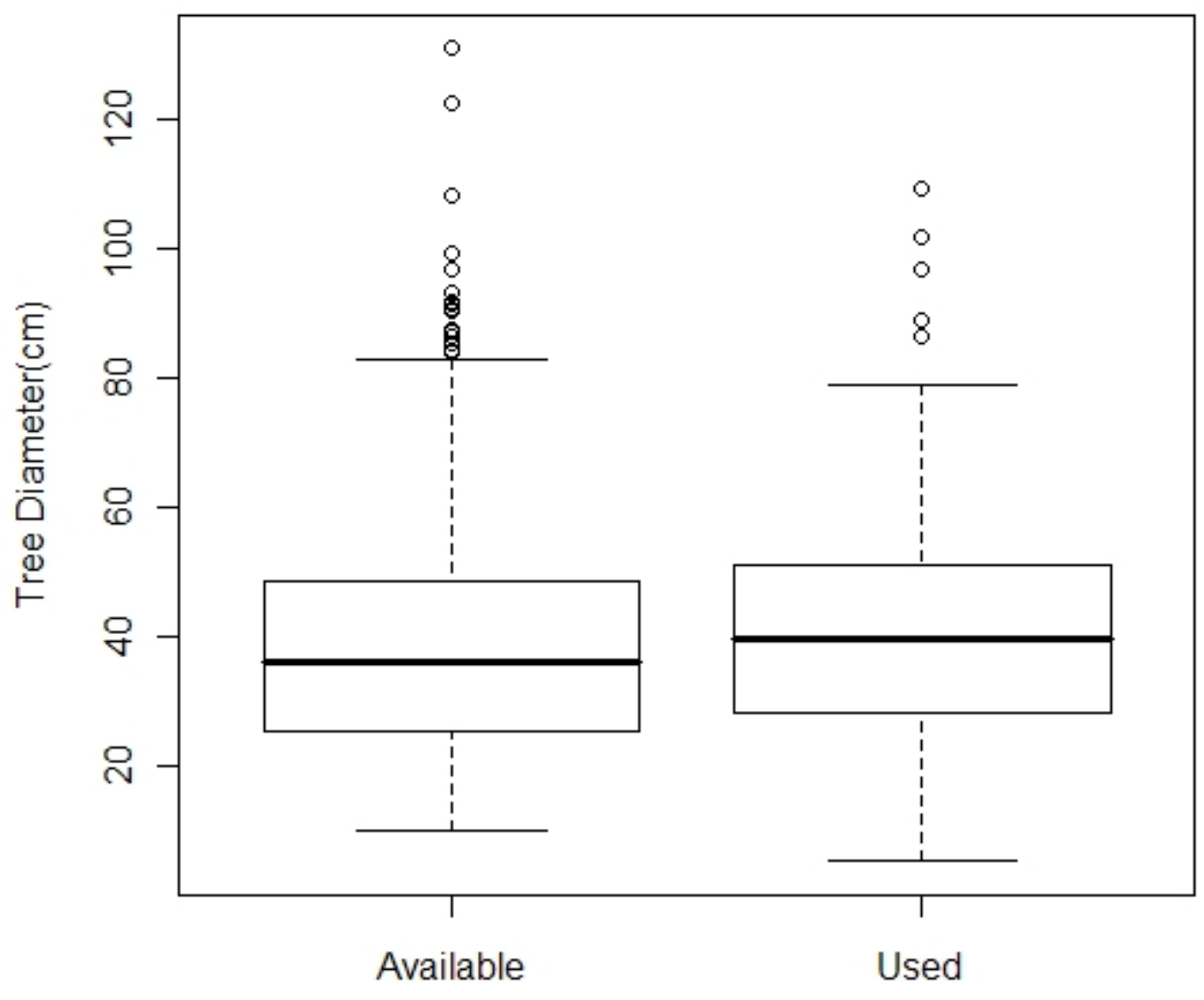

Figure 2: Similarities in tree diameter at breast height $(\mathrm{DBH})$ use $(\mathrm{n}=315)$ compared to availability $(n=1855)$ indicate that Cerulean Warblers select trees irrespective of diameter based on boxplots depicting each samples five-number summary (includes: minimum, maximum, Q1, Q3, and median with outliers depicted as circles). 


\section{CHAPTER 3}

Foraging ecology and tree species selection of five Neotropical migrants in West Virginia. 
Abstract

Species resource requirements are an important component of habitat selection. We investigated foraging ecology and tree species selection of five Neotropical migrant species; American Redstart (Setophaga ruticilla), Black-and-white Warbler (Mniotilta varia), Hooded Warbler (Wilsonia citrine), Red-eyed Vireo (Vireo olivaceus), and Scarlet Tanager (Piranga olivacea) at three study sites in West Virginia before (2006) and after (2007) habitat disturbance from silvicultural treatments. Tree species availability, based on importance values (IV) calculated from relative density, frequency, and basal area, differed from tree species used for foraging pre and post-harvest $(\mathrm{P}<0.01)$. Aerial maneuvers increased post-treatment for all species except Black-and-white Warbler. At the avian guild level, sugar maples (Acer saccharum) were preferred while red oaks (Quercus spp) were avoided. Tree species selection changed little postharvest. Red-eyed Vireo and post-harvest American Redstarts exhibited significant tree species selection preferences $(\mathrm{P}<0.05)$ while Scarlet Tanagers were near-significant in tree species selection $(\mathrm{P}=0.06)$. Understanding habitat use patterns, in response to habitat disturbance, is important for the management and conservation of Neotropical migrant species.

Keywords: foraging ecology, Neotropical Migrant, silviculture, tree species use 
Morphological foraging adaptations and patchy distribution of resources might result in a foraging preference for certain tree species as more selective foragers are distributed less evenly across the landscape (Holmes and Robinson 1981, Parrish 1995a, b). The study of habitat selection has received considerable attention (Jones 2001). Habitat structure could be essential to habitat selection (Morse 1985, Conner and Dickson 1997), and habitat models exist to explain patterns in species abundance and distribution (MacArthur and Pianka 1966, Rosenzweig 1991). However, more thorough evaluation of avian foraging habitat selection and an understanding of avian community-level response is needed. Only two studies quantified selection of tree species for foraging while accounting for relative density, relative frequency, and relative basal area. Gabbe et al. (2002) quantified tree species use by thirteen foraging insectivorous passerines in southern Illinois finding that most species foraged in tree species disproportionate from availability. Similarly, Holmes and Robinson (1981) found that ten focal species they studied in New Hampshire foraged in tree species disproportionate from availability.

Understanding the influence that variability in forest structure has on avian abundance, distribution, and reproductive fitness has conservation implications for forest management (Marzluff et al. 2000). Forest vegetation structure is an important and well known component of avian habitat selection (MacArthur and MacArthur 1961, Cody 1968, Franzreb 1983, Brown 1992, Petit and Petit 1996, Jones 2001). Selection of suitable habitat is often tied to different stages of succession (Freedman et al. 1981, Hunt 1998), and silvicultural practices can imitate natural disturbance regimes by creating a more diverse habitat mosaic (Greenberg et al. 1995), which is an important consideration for habitat management (Probst and Weinrich 1993). Neotropical migrants have a range of responses to forest openings which are not fully understood (Morse 1985, Thompson et al. 1992, Thompson et al. 2000, Germaine et al. 1997). Silvicultural 
treatments can influence invertebrate distributions (Duguay et al. 2000, Summerville and Crist 2002), which is important considering that Lepidoptera are an important food source for Neotropical migratory passerines.

Understanding foraging habitat selection and the avian community response to changes in habitat structure influences Neotropical migrant conservation. In this paper we present foraging data for five Neotropical migrants: American Redstart, Black-and-white Warbler, Hooded Warbler, Red-eyed Vireo, and Scarlet Tanager. The specific objectives were to determine if each species' foraging behaviors were influenced by silvicultural practices and determine if any species select tree species disproportionately from availability. Tree species selection has received little attention and is of particular importancefor foraging substrate selection because it is directly related to acquiring adequate food resources. We studied the interaction between foraging ecology and substrate use under the influence of silvicultural practices to help guide management activities associated with silviculture in the central Appalachians. Out results are compared to the literature on foraging tree species selection to discern whether broad patterns exist.

\section{Methods}

Study area.

Research was conducted in 2006 and 2007 at three study sites in West Virginia. Study sites were located on the Lewis Wetzel Wildlife Management Area (LWWMA) in Wetzel County, forested private timberlands in Wyoming County (WYO), and the Monongahela National Forest (MON) in Randolph County. In 2006, all sites were primarily mature, second-growth, mixed mesophytic and northern hardwood forests. Predominant tree species at LWWMA and MON include maple 
sp. (Acer spp.), oak sp. (Quercus spp.), hickory sp. (Carya spp.), and tulip poplar (Liriodendron tulipifera). The WYO study site had similar predominant tree species although maples were a less significant component. Elevation at WYO was 550 - 650m, LWWMA was $300-400 \mathrm{~m}$, and MON was $650-800 \mathrm{~m}$. LWWMA and WYO study areas were characterized by narrow valleys with steep slopes and convoluted ridges with no prevailing orientation. The MON site is part of the Ridge and Valley Province where ridge orientation is northeast to southwest.

Four, 20 ha, plots were placed along ridge-tops on northern and eastern aspects at each site. Each plot was generally rectangular and had two, 5 ha uncut buffers located on the plot ends and a central 10 ha treatment block. The treatment area was randomly assigned one of four timber harvesting treatments including an unharvested control, a light treatment similar to a single tree selection harvest, an intermediate treatment approximating a shelterwood harvest, and a heavy treatment approximating a deferment harvest. Residual basal area (RBA) for harvest treatment types was $14.5-24.3 \mathrm{~m}^{2} / \mathrm{ha}, 11.5-17.1 \mathrm{~m}^{2} / \mathrm{ha}$, and 3.0-9.6 $\mathrm{m}^{2} / \mathrm{ha}$. The treatment mosaic resulted in 3, 10 ha segments receiving a timber harvest and a combined 50 ha of uncut forest at each study site. Timber harvests were implemented through commercial logging in fall and winter of 2006.

Surveys

Each 20 ha plot was searched for five species of foraging Neotropical migrants, several times per week, between 1 May and 15 July, 2006 and 2007. For each foraging bird located, we recorded a single point foraging observation to ensure independence of observations (Hejl et al. 1990). When a foraging bird was first detected, the observer waited 5 seconds before recording any behavior to avoid bias associated with obvious maneuvers (Hejl et al. 1990). Multiple 
foraging observations per individual per day were recorded with a minimum of 60 minutes between observations. The 60 minute window allows for statistical independence among observations; 1 minute windows have been considered a biologically independent timeframe for Neotropical migrants (Barg et al. 2005).

Data recorded for each observation were foraging maneuver, forest structure, adjacency to forest gaps, and tree species occupied. We defined two aerial foraging maneuvers and two near-perch maneuvers similar to Remsen and Robinson (1990). The aerial maneuvers were aerial hawk, the traditional flycatcher maneuver, and sally-glean which was used to glean sessile prey from vegetative surfaces. The near-perch maneuvers were vegetation pick, a pick maneuver towards vegetative surfaces, and woody picks directed towards branches or tree bark. Due to difficulty in determining sex for Black-and-white Warblers and Red-eyed Vireo in addition to subtle sex determination issues with second-year male American Redstarts and some female Hooded Warblers having black caps all data was not separated out by sex.

Forest structure was recorded as position within the vegetative column and was divided into under-story, mid-story, and canopy. Three categories of canopy gaps were identified: no gap, a small gap similar to a single tree fall gap or single tree removal, and large gap such as a road, tree group removal, or a wildlife food plot. For the 5 focal species, we combined data from foraging observations across study areas and silvicultural treatment plots for each year by species.

To determine whether the target species foraged on trees proportional to availability, we used a 2.5-factor metric prism to quantify tree species availability. We recorded species of each live tree and DBH (diameter at breast height) of each tree or snag in the prism plot. Locations of prism plots were randomly selected with 20 prism plots per study plot (one per ha). Importance values 
(IV) for each tree species were then calculated from relative density, relative frequency, and relative basal areas to determine tree species preference (Holmes and Robinson 1981, Gabbe et al. 2002). Importance values were converted into importance percentages to characterize overall tree species availability to foraging individuals. Tree species with IV $\leq 2 \%$ had too few foraging observations to be included in analyses. Due to inconsistencies in identification of some trees to species, we grouped all hickory and red oak species into their respective single categories of hickory and red oak. Twelve tree species or groups met the $2 \%$ IV criteria.

To compare data pre- and post-harvest, we combined foraging observations from the LWWMA and WYO study areas for analysis. The MNF dataset was excluded because it did not contain pre-harvest data. We excluded foraging observations from the heavy treatment plot because of the extremely small sample size in this treatment (pre-harvest $n=31$, post-harvest $n=$ 17). Data were combined from low and intermediate harvests to increase sample size for the harvested treatment. Previous research on Cerulean Warblers found similar foraging responses to these two harvest treatments (G. George, Chapter 2). Unharvested controls and buffer areas were combined into one category, uncut forest, because few foraging observations occurred in controls.

Statistical Analyses

We compared foraging variables (foraging maneuver, forest structure, adjacency to forest gaps, and tree species occupied) between pre-treatment and post-treatment seasons with the Fisher Exact test because some categories had expected values of less than five (Conover 1999). Paired chi-square tests were used to discern which foraging categories were different from pre- 
to post- harvest with $\alpha=0.01$ for significance to be more conservative while performing multiple tests.

To quantify tree species selection, we compared observed foraging frequencies to expected frequencies (Holmes and Robinson 1981, Gabbe et al. 2002) using a chi-square goodness-of-fit test with Monte Carlo estimates of exact $p$-values for probability. Preference indices, deviation of observed versus expected values, are used to depict tree species preference or avoidance by bird species. We completed a separate analysis for uncut forest and harvest areas for each year and species. Additionally, to assess avian guild-level tree species selection, we analyzed data combined across the five focal species. Importance values, calculated for each tree species, were multiplied by the total number of observations defining the expected frequencies and were compared to observed frequencies. Preference indices, deviation of observed versus expected values, are used to depict tree species preference or avoidance. A comparison of light harvest, intermediate harvest, and uncut forest between years was analyzed for selection of tree species pre- and post harvest based on standardized residual comparison with a paired t-test, (R Development Core Team 2007).

All analyses were computed within the R statistical language (R Development Core Team 2007). We set $\alpha=0.05$ for significance except for paired chi-square tests.

Results

General Foraging Behavior and Habitat

In both years, Black-and-white Warbler most frequently used wood picks, while American Redstart, Hooded Warbler, Red-eyed Vireo, and Scarlet Tanager primarily used vegetation picks and sally-gleans (Table 1). Red-eyed Vireos used aerial maneuvers similarly 
between years while all other species increased their use of aerial maneuvers in the 2007 postharvest year.

Scarlet Tanagers foraged in the canopy pre- and post-harvest (Table 1). The mid-story was primarily used for foraging by American Redstarts, Black-and-white Warbler, and Hooded Warbler. Although Red-eyed Vireos foraged primarily in the mid-story during the 2006 preharvest year, they increased their foraging in the canopy post-harvest (Table1). All target species decreased their use of mid-story post harvest, although American Redstarts, Black-and-white Warblers and Hooded Warblers still used mid-story most often post-harvest (Table 1).

All species foraged adjacent to canopy gaps for $>50 \%$ of foraging observations preharvest and $\geq 73 \%$ post-harvest (Table 1). When comparing no gap, small gap, and large gap, pre-harvest Hooded Warblers and Red-eyed Vireos primarily foraged away from canopy gaps. Scarlet Tanagers most often foraged in association with small forest gaps. Large forest openings were regularly used by all species, particularly post-harvest.

\section{Effects of Silvicultural Treatments}

Within uncut forest areas, use of foraging maneuvers did not change from pre- to postharvest years for any focal species (Table 2). However, within harvested areas, a significant difference occurred for American Redstart $(\mathrm{P}=0.03)$ and near-significance was detected for Hooded Warblers $(\mathrm{P}=0.06)$. Both species greatly reduced use of vegetation picks and increased use of aerial hawks (Table 2).

In uncut forest areas, we found no significant difference in use of canopy strata for any focal species, pre- to post-harvest years (Table 3). Within harvested areas, three focal species had a significant difference in use of canopy strata between years (Hooded Warbler $\mathrm{P}=0.01$, 
Red-eyed Vireo $\mathrm{P}=0.04$, and Scarlet Tanager $\mathrm{P}=0.01$ ). All three species greatly reduced use of the mid-story. Hooded Warblers increased understory use, while both Red-eyed Vireo and Scarlet Tanager increased their foraging in the canopy (Table 3).

Within uncut forest areas, only Hooded Warblers had differences in gap use between preand post-harvest years $(\mathrm{P}=0.02)$. They increased their use of small and large canopy gaps (Table 4). Within harvested areas, gap use for all focal species changed significantly from preto post-harvest $(\mathrm{P}<0.01)$. Black-and-white Warblers, Hooded Warblers, Red-eyed Vireos, and Scarlet Tanagers all primarily foraged away from canopy gaps during the 2006 pre-harvest year; American Redstarts mostly foraged adjacent to large canopy gaps. All focal species increased use of large canopy gaps post-harvest (Table 4).

\section{Tree Species Selection}

Tree species selection based on combined foraging data for all focal avian species on all plots combined ( $\mathrm{n}=679$ foraging observations) was statistically different from availability both years (Table 5). Sugar maples were preferred and red oaks were avoided both seasons, while chestnut oak was preferred pre-treatment and avoided post-treatment. Tulip poplar was avoided pre-treatment, then used in proportion to availability post-treatment. Foraging generally occurred in the remaining tree species proportional to availability (Table 5).

At the guild level, significant selection of tree species was not detected in either the light treatment or intermediate treatment pre-harvest (Table 6) but selection occurred post-harvest in the light harvest with avoidance of the red oak group and preference of sugar maples. In uncut forests, preference occurred in both years with avoidance of the red oak group and preference of sugar maples (Table 6). Additionally, we found no significant change in preference indices of 
tree species within the light harvest, intermediate harvest, and uncut forest between years $(\mathrm{t}=$ $0.62, \mathrm{P}=0.55 ; \mathrm{t}=-0.07, \mathrm{P}=0.95 ;$ and $\mathrm{t}=-0.41, \mathrm{P}=0.69$, respectively).

Some focal species selected tree species disproportionately from availability (Table 7) including pre- and post-harvest Red-eyed Vireos and post-harvest American Redstarts. Scarlet tanagers were near statistical significance both years $(\mathrm{P}=0.06$ each year $)$. Pre-and post harvest Red-eyed Vireos selected sugar maples but avoided red oak. Post-harvest American Redstarts selected sugar maple and tulip poplar but they avoided red oak and chestnut oak. Scarlet Tanagers selected sugar maple and avoided red oak both years. Additionally, Scarlet Tanagers selected chestnut oak, and avoided tulip poplar pre-treatment but avoided chestnut oak and selected white oak post-harvest.

\section{Discussion}

Influence of silvicultural practices on foraging behavior and ecology

Forests are dynamic systems with varying micro-habitat characteristics associated with different stages of succession. Selection of suitable habitat is often tied to these different stages (Hunt 1998). Hunt (1998) found that the pattern of habitat succession in Vermont and New Hampshire resulted in more mature forest and less early successional habitat which negatively affected American Redstart populations. Silvicultural practices can imitate natural disturbance regimes and create a more diverse habitat mosaic (Greenberg et al. 1995). Understanding that some species prefer certain stages of forest succession allows an opportunity for forest management to be tailored to meet the habitat requirements of particular species (Probst and Weinrich 1993). Warbler abundance can vary by species to the different silvicultural practices (Freedman et al. 1981, Duguay et al. 2001, McDermott 2007, McDermott and Wood 2008). 
Comparing logged and natural environments (Franzreb 1983) found that tree species use varied between sites due to selective tree species removal; aspen was not removed from the logged areas and its use increased from 5\% to 53\%. In harvested areas, the canopy was removed resulting in an overall decrease in foraging height (Franzreb 1983).

Many Neotropical migrants have a negative association with forest openings while others show either indifference or respond positively (Morse 1985, Thompson et al. 1992, Germaine et al. 1997). Silvicultural harvests influenced foraging behavior differently among focal species, although generally foraging birds increased their use of aerial maneuvers (Table 2) and of large canopy gaps (Table 4) while decreasing forest mid-story use (Table 3 ). The use of canopy gaps was potentially related to resource availability. Different silvicultural treatments influence invertebrate distributions, the major food source for Neotropical migratory birds (Summerville and Crist 2002, Duguay et al. 2000). Heavy harvests had reduced invertebrate species richness (Summerville and Crist 2002) and biomass (Duguay et al. 2000). Summerville and Crist (2002) found no difference in species richness between selectively logged and unlogged stands. Ramifications could be important considering that Lepidoptera are the most common and diverse group of invertebrates in eastern deciduous forests (Hammond and Miller 1998).

Post-harvest forest gaps were regularly used for foraging within a habitat mosaic of mature forest and forests with openings. All focal species increased their use of large canopy gaps, which indicates tolerance for larger gaps as suitable foraging locations. Increased primary productivity associated with increased light levels found in canopy gaps might result in increased food availability (Fogden 1972). A warmer microclimate associated with increased light levels can result in increased abundance and activity of flying insects (Blake and Hoppes 1986, Smith and Dallman 1996, Gorham et al. 2002), which could help explain the increased use of aerial 
foraging maneuvers post-harvest when there were more canopy gaps. Additionally, nitrogen is known to be an important limiting factor in growth of invertebrate herbivores (Mattson 1980, Scriber and Slansky 1981, Mattson et al. 1991, Fortin and Mauffette 2002). Increased light levels are correlated with increased levels of nitrogen within leaves (Hemming and Lindroth 1995, Fortin and Mauffette 2002) potentially resulting in an increase in food availability for foraging birds. However, Kilgo (2005) found a negative continuum in foliage-dwelling arthropod abundance from forest edge to interior forest, defined as $>100 \mathrm{~m}$, and concluded that Hooded Warblers encountered less prey, and therefore, foraged less proficiently, lower attack rate, near gaps.

Tree Species Selection

Varying degrees of tree species selectivity, between years, were found among the five focal bird species with a mixture of selective and more generalist species (Table 6). Gabbe et al. (2002) found that most species selected tree species disproportional to their availability with the exception of Yellow-throated Vireo based on foraging observations on thirteen bird species. Holmes and Robinson (1981), investigating ten bird species, found all were selective of tree species. It appears that our focal species were less selective with only two species displaying significant, or near-significant, selection during both years. Therefore, in West Virginia, considerations of tree species composition may be less important component to silviculture for some, but not all, bird species.

Sugar maple was an important tree species for foraging Neotropical migrants in West Virginia. Holmes and Robinson (1981) found sugar maple to be avoided in New Hampshire where yellow birch was strongly preferred while Gabbe et al. (2002) found hickories to be 
important on study plots absent of sugar maple. It is important to acknowledge that preferences among migrants could vary by location and might be influenced by local tree species diversity and abundance. Holmes and Robinson (1981) had a less diverse forest and thus a small number of different tree species. Gabbe et al. (2002) had a diverse forest although the tree species composition was different from West Virginia with few similar tree species available between West Virginia and Illinois. Of the 19 tree species considered by Gabbe et al. (2002) only 1, red maple, was represented in our study.

Our study had two avian species in common with Holmes and Robinson (1981) and Gabbe et al. (2002), Red-eyed Vireo and Scarlet Tanager. All three studies found each to be selective of tree species. In New Hampshire, Red-eyed Vireos displayed a slight preference for sugar maple (Holmes and Robinson 1981), in West Virginia they preferred sugar maple although in the absence of sugar maple Gabbe et al. (2002) found they selected sugarberry (Celtis laevigata). Red oak was avoided in West Virginia, white ash (Fraxinus americana) was avoided in New Hampshire (Holmes and Robinson 1981) and pumpkin ash (F. profunda) was avoided in Illinois (Gabbe et al. 2002). West Virginia sites did not have a dominant ash species. Scarlet Tanagers preferred sugar maple in West Virginia, yellow birch (Betula alleghaniensis) in New Hampshire (Holmes and Robinson 1981) and cherrybark oak (Quercus pagoda) in Illinois (Gabbe et al. 2002). Although Scarlet Tanagers preferred sugar maple in West Virginia it was avoided in New Hampshire as was overcup oak (Q. lyrata) and sugarberry in Illinois.

Sugar Maples, the most preferred tree species for foraging in our research, is shade tolerant allowing adequate regeneration from smaller forest openings. Under this scenario, wildlife managers can reduce the size of forest gaps while encouraging the growth of a tree species preferred by foraging birds and a tree of economic importance. Oaks, due to their 
economic value, are an important timber tree in the central Appalachian Mountains. Silvicultural practices implemented to regenerate oaks might result in decreased avian foraging efficiency considering oak species, in general, were not preferred for foraging. Consistent avoidance was most obvious with the red oak group (Table 7) possibly due to relatively high tannin levels in red oak leaves (Wood 2005). Variation in tannin levels among tree species influence the distribution of Lepidoptera larva (Murakami 1998). Some Lepidoptera larva species are known to have difficulty digesting leaves with higher tannin levels which results in poor growth, and therefore, reduced overall biomass (Karowe 1989).

Marshall and Cooper (2004) determined that abundance of Lepidoptera larva varied during the breeding season within and among tree species. Highest densities of larva were found in the pre-nesting season with lower densities during the breeding season. Marshall and Cooper (2004) found that red oak had comparable Lepidoptera larva abundance to maples, hickories, white oak, and chestnut oak (about 30 caterpillars/ kg leaf biomass). Because red oaks were avoided for foraging in our study, this suggests other factors, such as tannin levels, influenced tree species preferences.

In West Virginia, we identified Red-eyed Vireo and Scarlet tanager as specialists foraging on selected tree species; in contrast Black-and-white Warbler and Hooded Warbler were generalists. American Redstart were generalists the first year, then specialists the second (Table 5). Understanding if avian species are generalists or specialists is useful for understanding resource requirements and overall conservation needs. The degree of selection associated with tree species use is an indicator of how effectively species can respond to variation in resource availability. A management scenario intended for the more selective species might be the most 
effective approach. Generalist species will be less influenced by modifications of tree species availability while meeting the requirements of more selective species.

Acknowledgements

Funding for this work was provided by the National Fish and Wildlife Foundation, National Council for Air and Stream Improvement, U.S. Fish and Wildlife Service, West Virginia

Division of Natural Resources, and U.S. Forest Service Monongahela National Forest. We thank P. McElhone, M Shumar, V. Lane, and numerous field technicians for assistance in data collection. We also thank S. Durham and L. Skrzypek for logistical support. We thank the U.S. Forest Service Monongahela National Forest, West Virginia Division of Natural Resources, Advantage Timberland, Forest Land Group and Wagner LTD for allowing us access to their properties and implementing harvests. Use of trade names does not imply endorsement by the Federal government.

\section{Literature Cited}

Barg, J. B., J. Jones, and R. J. Robertson. 2005. Describing breeding territories of migratory passerines: suggestions for sampling, choice of estimator, and delineation of core areas. Journal of Animal Ecology 74:139-149.

Blake, J. G., and W. G. Hoppes. 1986. Influence of resource abundance on use of tree-fall gaps by birds in an isolated woodlot. Auk 103: 328-340.

Brown, V. K. 1992. The effects of change in habitat structure during succession in terrestrial communities. Pp. 141-168 in (S. Bell, E McCoy and H. Mushinsky, eds.) Habitat structure: the physical arrangement of objects in space. Chapman and Hall, London, England.

Cody, M. L. 1968. On the method of resource division in grassland bird communities. American Naturalist. 192:107-147. 
Conner, R. N., and J. G. Dickson. 1997. Relationships between bird communities and forest age, structure, species composition and fragmentation in the West gulf coastal plain. Texas Journal of Science 49:123-138.

Conover, W. J. 1999. Practical nonparametric statistics. Wiley series in probability and statistics: Applied probability and statistics section. John Wiley \& Sons, Inc., New York, New York.

Duguay, J. P., P. B. Wood, and G. W. Miller. 2000. Effects of timber harvest on invertebrate biomass and avian nest success. Wildlife Society Bulletin 28:1123-1131.

Duguay, J. P. P. B. Wood, and J. V. Nichols. 2001. Song bird abundance and avian nest survival rates in forests fragmented by different silvicultural treatments. Conservation Biology 15:1405-1415.

Fogden, M. P. L., 1972. The seasonality and population of equatorial forest birds in Sarawak. Ibis 114:307-342.

Fortin, M. and Y. Mauffette. 2002. The suitability of leaves from different canopy layers for a generalist herbivore (Lepidoptera: Lasiocampidae) foraging on sugar maple. Canadian Journal of Forest Research 32:379-389.

Franzreb, K. E. 1983. A comparison of avian foraging behavior in unlogged and logged mixedconiferous forests. Wilson Bulletin 95:60-76.

Freedman, B., C. Beauchamp, I. A. McLaren, and S. I. Tingley. 1981. Forestry management practices and populations of breeding birds in a hardwood forest in Nova Scotia. Canadian Field-Naturalist 95:307-311.

Gabbe, A. P., S. K. Robinson, and J. D. Brawn. 2002. Tree-species preferences of foraging insectivorous birds: Implications for floodplain forest restoration. Conservation Biology 16:462-470.

Germaine, G. G., S. H. Vessy, and D. E. Capen. 1997. Effects of small forest openings on the breeding bird community in a Vermont hardwood Forest. Condor 99:708-718.

Gorham, L. E., S. L. King, B. D. Keeland, and S. Mopper. 2002. Effects of canopy gaps and flooding on homopterans in a bottomland hardwood forest. Wetlands 22:541-549.

Greenberg, C. H., L. D., Harris, and D. G. Neary. 1995. A comparison of bird communities in burned and salvaged-logged, clearcut, and forested Florida sand pine scrub. Wilson Bulletin. 107: 40-54.

Hammond P. C., and J. C. Miller. 1998. Comparison of the biodiversity of Lepidoptera within three forested ecosystems. Annals of the Entomological Society of America 91:323-328 
Hejl, S. J., J. Verner, and G. W. Bell. 1990. Sequential versus initial observation in studies of avian foraging. Pp 166-173 in (M. Morrison, C. Ralph, J. Verner, and J. Jehl, Jr. eds.) Studies in avian biology No:13. Avian foraging: Theory, methodology and application. Cooper Ornithological Society.

Hemming, J. D. C., and Lindroth, R.L. 1995. Intraspecific variation in aspen phytochemistry: effects on performance of gypsy moths and forest tent caterpillars. Oecologia 103:79-88.

Holmes, R. T., and S. K. Robinson. 1981. Tree species preference of foraging insectivorous birds in a northern hardwood forest. Oecologia 48:31-35.

Hunt, P. D. 1998. Evidence from a landscape population model of the importance of early successional habitat to the American Redstart. Conservation Biology 12:1377-1389.

Jones, J. 2001. Habitat selection studies in avian ecology: a critical review. Auk 118:557-562.

Karowe, D. N. 1989. Differential effect of tannic acid on two tree-feeding Lepidoptera: implications for theories of plant anti-herbivore chemistry. Oecologia 80:50-512.

Kilgo, J. C. 2005. Harvest-related edge effects on prey availability and foraging of hooded warbler in a bottomland hardwood forest. Condor 107:627-636.

MacArthur, R. H., and J. W. MacArthur. 1961. On bird species diversity. Ecology 42:594-598

MacArthur, R. H., and E. R. Pianka. 1966. On optimal use of a patchy environment. American Natiralist 100:603-609.

Marzluff, J. M., M. G. Raphael, and R. Sallabanks. 2000. Understanding the effects of forest management on avian species. Wildlife Society Bulletin 28:1132-1143.

Marshall, M. R. and R. J. Cooper. 2004. Territory size of a migratory songbird in response to caterpillar density and foliage structure. Ecology 85:432-445.

Mattson W. J. JR. 1980. Herbivory in relation to plant nitrogen content. Annual Reviews in Ecology and Systematics 11:119-161.

Mattson, W.J., R.A. Haack, R. K. Lawrence and S. S. Slocum. 1991. Considering the nutritional ecology of the spruce budworm in its management. Forest Ecology and Management 39:183-210.

McDermott, M. E. 2007. Breeding and post-breeding forest bird community dynamics in regenerating clearcuts and two-age harvests in the central Appalachians. Master's Thesis, West Virginia University. 
McDermott, M. E. and P. B. Wood. 2008. Short- and long-term implications of clearcut and two-age silviculture for conservation of breeding forest birds in the central Appalachians, USA. Biological Conservation 142:212-220.

Murakami, M. 1998. Foraging habitat shift in the narcissus fycatcher, Ficedula narcissina, due to the response of herbivorous insects to the strengthening defenses of canopy trees. Ecological Research 13:73-82.

Morse, D. H. 1985. Habitat selection in North American parulid warblers. Pp 131-157 in (M. L. Cody ed.) Habitat selection in birds. Academic Press, San Diego, CA.

Parrish, J. D. 1995a. Effects of needle architecture on warbler habitat selection in a coastal spruce forest. Ecology 76:1813-1820.

Parrish, J. D. 1995b. Experimental evidence for intrinsic microhabitat preferences in the Blackthroated Green Warbler. Condor 97:935-943.

Petit, L. J. and D. R. Petit. 1996. Factors governing habitat selection by Prothonotary Warblers: Field tests on the Fretwell-Lucas models. Ecological Monographs 66:367-387.

Probst, J. R. and J. Weinrich. 1993. Relating Kirtland's warbler population to changing landscape composition and structure. Landscape Ecology 8:257-271.

R Development Core Team (2007). R: A language and environment for statistical computing. $\mathrm{R}$ Foundation for Statistical Computing, Vienna, Austria. ISBN 3-900051-07-0, URL http://www.R-project.org.

Remsen, J. V., JR. and S. K. Robinson. 1990. A classification scheme for foraging behavior of birds in terrestrial habitats. Pp 144-160 in (M. Morrison, C. Ralph, J. Verner, and J. Jehl, Jr. eds.) Studies in avian biology No:13. Avian foraging: Theory, methodology and application. Cooper Ornithological Society.

Rosenzweig, M. L. 1991. Habitat selection and population interactions: The search for mechanism. American Naturalist 137 (Supplement):5-28.

Scriber, J.M., and F. Slansky, Jr. 1981. The nutritional ecology of immature insects. Annual Review of Emtomology 26: 183-211.

Smith, R. and M. Dallman. 1996. Forest gap use by breeding Black-throated Green Warblers. Wilson Bulletin 108:588-591.

Summerville, K. S. and T. O. Crist. 2002. Effects of timber harvest on forest Lepidoptera: community, guild, and species response. Ecological Applications, 12:820-835. 
Thompson, F. R., J. D. Brawn, S Robinson, J. Faaborg, and R. L. Clawson. 2000. Approaches to investigate effects of forest management on birds in eastern deciduous forests: How reliable is our knowledge? Wildlife Society Bulletin 28:1111-1122.

Thompson, R., III, W. D. Dijak, T. G. Kulowiec, and D. A. Hamilton. 1992. Breeding bird populations in Missouri Ozark forests with and without clearcutting. Journal of Wildlife Management. 56:23-30.

Wood, M. D. 2005. Tannin and lipid content of acorns in scatterhoards and larderhoards. Northeastern Naturalist, 12:463-472. 
Table 1: Total number and percent of observations for each species by foraging variable for all study areas and plots combined. Data are presented for the pre-harvest (2006) and post-harvest (2007) years. Focal species are American Redstart (AMRE), Black-and-white Warbler (BAWW), Hooded Warbler (HOWA), Red-eyed Vireo (REVI), and Scarlet Tanager (SCTA).

\begin{tabular}{|c|c|c|c|c|c|c|c|c|c|c|c|c|c|c|c|c|c|c|c|c|}
\hline \multirow[b]{3}{*}{ Variable } & \multicolumn{4}{|c|}{ AMRE } & \multicolumn{4}{|c|}{ BAWW } & \multicolumn{4}{|c|}{ HOWA } & \multicolumn{4}{|c|}{ REVI } & \multicolumn{4}{|c|}{ SCTA } \\
\hline & \multicolumn{2}{|c|}{ Pre } & \multicolumn{2}{|c|}{ Post } & \multicolumn{2}{|c|}{ Pre } & \multicolumn{2}{|c|}{ Post } & \multicolumn{2}{|c|}{ Pre } & \multicolumn{2}{|c|}{ Post } & \multicolumn{2}{|c|}{ Pre } & \multicolumn{2}{|c|}{ Post } & \multicolumn{2}{|c|}{ Pre } & \multicolumn{2}{|c|}{ Post } \\
\hline & $\mathrm{n}$ & $\%$ & $\mathrm{n}$ & $\%$ & $\mathrm{n}$ & $\%$ & $\mathrm{n}$ & $\%$ & $\mathrm{n}$ & $\%$ & $\mathrm{n}$ & $\%$ & $\mathrm{n}$ & $\%$ & $\mathrm{n}$ & $\%$ & $\mathrm{n}$ & $\%$ & $\mathrm{n}$ & $\%$ \\
\hline \multicolumn{21}{|c|}{ Foraging Maneuvers } \\
\hline Vegetation Pick & 26 & 41.3 & 25 & 23.6 & 4 & 13.3 & 1 & 2.0 & 52 & 46.8 & 40 & 27.8 & 29 & 40.3 & 60 & 37.5 & 27 & 36.5 & 45 & 27.3 \\
\hline Wood-Pick & 11 & 17.5 & 21 & 19.8 & 25 & 83.3 & 41 & 83.7 & 15 & 13.5 & 34 & 23.6 & 9 & 12.5 & 29 & 18.1 & 15 & 20.3 & 35 & 21.2 \\
\hline Sally-Glean & 22 & 34.9 & 40 & 37.7 & 1 & 3.3 & 3 & 6.1 & 40 & 36.0 & 54 & 37.5 & 34 & 47.2 & 60 & 37.5 & 29 & 39.2 & 67 & 40.6 \\
\hline Aerial Hawk & 4 & 6.3 & 20 & 18.9 & 0 & 0.0 & 4 & 8.2 & 4 & 3.6 & 16 & 11.1 & 0 & 0.0 & 11 & 6.9 & 3 & 4.1 & 18 & 10.9 \\
\hline \multicolumn{21}{|l|}{ Forest Structure } \\
\hline Understory & 6 & 9.5 & 10 & 9.4 & 6 & 20.0 & 8 & 16.3 & 23 & 20.7 & 60 & 41.7 & 4 & 5.6 & 12 & 7.5 & 6 & 8.1 & 20 & 12.1 \\
\hline Mid-story & 44 & 69.8 & 58 & 54.7 & 23 & 76.7 & 33 & 67.3 & 74 & 66.7 & 66 & 45.8 & 49 & 68.1 & 71 & 44.4 & 31 & 41.9 & 51 & 30.9 \\
\hline Canopy & 13 & 20.6 & 38 & 35.8 & 1 & 3.3 & 8 & 16.3 & 14 & 12.6 & 18 & 12.5 & 19 & 26.4 & 77 & 48.1 & 37 & 50.0 & 94 & 57.0 \\
\hline \multicolumn{21}{|l|}{ Gap Adjacency } \\
\hline No Gap & 18 & 28.6 & 20 & 18.9 & 11 & 36.7 & 9 & 18.4 & 54 & 48.6 & 16 & 11.1 & 33 & 45.8 & 43 & 26.9 & 23 & 31.1 & 31 & 18.8 \\
\hline Small Gap & 19 & 30.2 & 19 & 17.9 & 8 & 26.7 & 8 & 16.3 & 18 & 16.2 & 27 & 18.8 & 22 & 30.6 & 24 & 15.0 & 28 & 37.8 & 27 & 16.4 \\
\hline Large Gap & 26 & 41.3 & 67 & 63.2 & 11 & 36.7 & 32 & 65.3 & 39 & 35.1 & 101 & 70.1 & 17 & 23.6 & 93 & 58.1 & 23 & 31.1 & 107 & 64.8 \\
\hline
\end{tabular}


Table 2: Comparison of foraging maneuver use between pre- (2006) and post-harvest (2007) years for uncut forest and harvested area (low and intermediate harvests combined) combining the study sites. Included are P-values for Fisher's exact tests comparing pre- and post-treatment years to discern difference between years by forest or harvest area. Paired chi-square tests were used to discern which foraging categories were different from pre- to post- harvest with $\alpha=0.01$ for significance. Significant results denoted by asterisk.

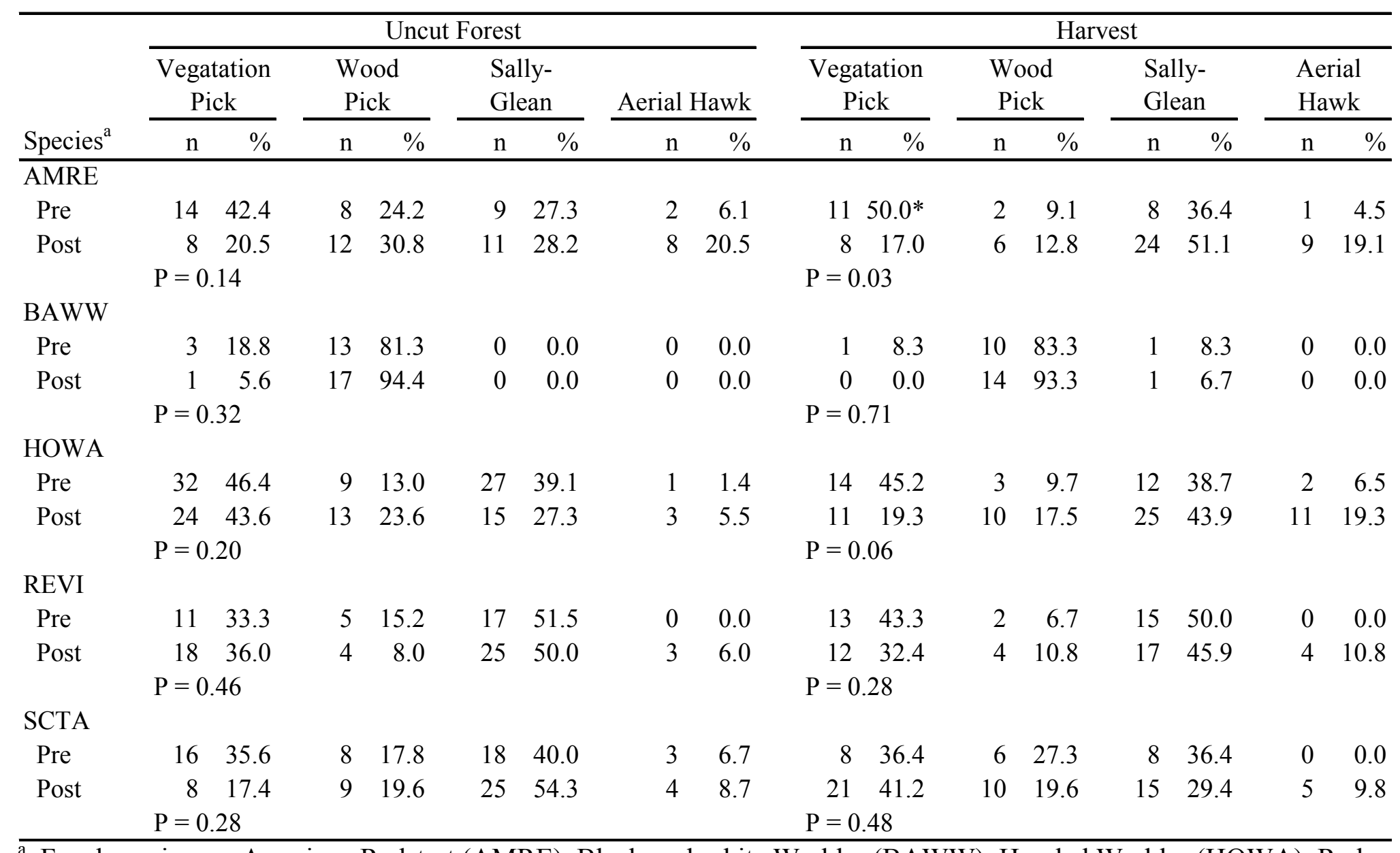

\footnotetext{
${ }^{a}$ Focal species are American Redstart (AMRE), Black-and-white Warbler (BAWW), Hooded Warbler (HOWA), Red-eyed Vireo (REVI), and Scarlet Tanager (SCTA)
} 
Table 3: Comparison of forest structure use between pre- (2006) and post-harvest (2007) years for uncut forest and harvested area (low and intermediate harvests combined) combining the study sites. Included are P-values for Fisher's exact tests comparing pre- and post-treatment years to discern difference between years by forest or harvest area. Paired chi-square tests were used to discern which foraging categories were different from pre- to post- harvest with $\alpha=0.01$ for significance. Significant results denoted by asterisk.

\begin{tabular}{|c|c|c|c|c|c|c|c|c|c|c|c|c|}
\hline \multirow[b]{3}{*}{ Species $^{\mathrm{a}}$} & \multicolumn{6}{|c|}{ Uncut Forest } & \multicolumn{6}{|c|}{ Harvest } \\
\hline & \multicolumn{2}{|c|}{ Understory } & \multicolumn{2}{|c|}{ Mid-story } & \multicolumn{2}{|c|}{ Canopy } & \multicolumn{2}{|c|}{ Understory } & \multicolumn{2}{|c|}{ Mid-story } & \multicolumn{2}{|c|}{ Canopy } \\
\hline & $\mathrm{n}$ & $\%$ & $\mathrm{n}$ & $\%$ & $\mathrm{n}$ & $\%$ & $\mathrm{n}$ & $\%$ & $\mathrm{n}$ & $\%$ & $\mathrm{n}$ & $\%$ \\
\hline \multicolumn{13}{|l|}{ AMRE } \\
\hline Pre & 3 & 9.1 & 23 & 69.7 & 7 & 21.2 & 1 & 13.6 & 14 & 63.6 & 5 & 22.7 \\
\hline Post & 3 & 7.7 & 23 & 59.0 & 13 & 33.3 & 2 & 4.3 & 28 & 59.6 & 17 & 36.2 \\
\hline & \multicolumn{6}{|c|}{$P=0.50$} & \multicolumn{4}{|c|}{$\mathrm{P}=0.30$} & & \\
\hline \multicolumn{13}{|l|}{ BAWW } \\
\hline Pre & 5 & 31.3 & 10 & 62.5 & 1 & 6.3 & 1 & 8.3 & 11 & 91.7 & 0 & 0.0 \\
\hline Post & 2 & 11.1 & 13 & 72.7 & 3 & 16.7 & 1 & 6.7 & 12 & 80.0 & 2 & 13.3 \\
\hline & \multicolumn{6}{|c|}{$\mathrm{P}=0.29$} & \multicolumn{6}{|c|}{$P=0.74$} \\
\hline \multicolumn{13}{|l|}{ HOWA } \\
\hline Pre & 14 & 20.3 & 46 & 66.7 & 9 & 13.0 & & $19.4^{*}$ & 20 & 64.5 & 5 & 16.1 \\
\hline Post & 17 & 30.9 & 30 & 54.5 & 8 & 14.5 & & 50.9 & 24 & 42.1 & 4 & 7.0 \\
\hline & \multicolumn{6}{|c|}{$\mathrm{P}=0.32$} & \multicolumn{6}{|c|}{$\mathrm{P}=0.01$} \\
\hline \multicolumn{13}{|l|}{ REVI } \\
\hline Pre & 1 & 3.0 & 23 & 69.7 & 9 & 27.3 & 3 & 10.0 & 19 & 63.3 & 8 & 26.7 \\
\hline Post & 5 & 10.0 & 26 & 52.0 & 19 & 38.0 & 1 & 2.7 & 16 & 43.2 & 20 & 54.1 \\
\hline & \multicolumn{6}{|c|}{$\mathrm{P}=0.22$} & \multicolumn{6}{|c|}{$P=0.04$} \\
\hline \multicolumn{13}{|l|}{ SCTA } \\
\hline Pre & 4 & 8.9 & 17 & 37.8 & 24 & 53.3 & 1 & 4.5 & 12 & $54.5^{*}$ & 9 & 40.9 \\
\hline Post & 2 & 4.3 & 14 & 30.4 & 30 & 65.2 & 8 & 15.7 & 10 & 19.6 & 33 & 64.7 \\
\hline & \multicolumn{6}{|c|}{$P=0.43$} & \multicolumn{6}{|c|}{$\mathrm{P}=0.01$} \\
\hline
\end{tabular}

${ }^{\mathrm{a}}$ Focal species are American Redstart (AMRE), Black-and-white Warbler (BAWW), Hooded Warbler (HOWA), Red-eyed Vireo (REVI), and Scarlet Tanager (SCTA). 
Table 4: Comparison of forest gap use between pre- (2006) and post-harvest (2007) years for uncut forest and harvested area (low and intermediate harvests combined) combining the study sites. Included are P-values for Fisher's exact tests comparing pre- and post-treatment years to discern difference between years by forest or harvest area. Paired chi-square tests were used to discern which foraging categories were different from pre- to post- harvest with $\alpha=0.01$ for significance. Significant results denoted by asterisk.

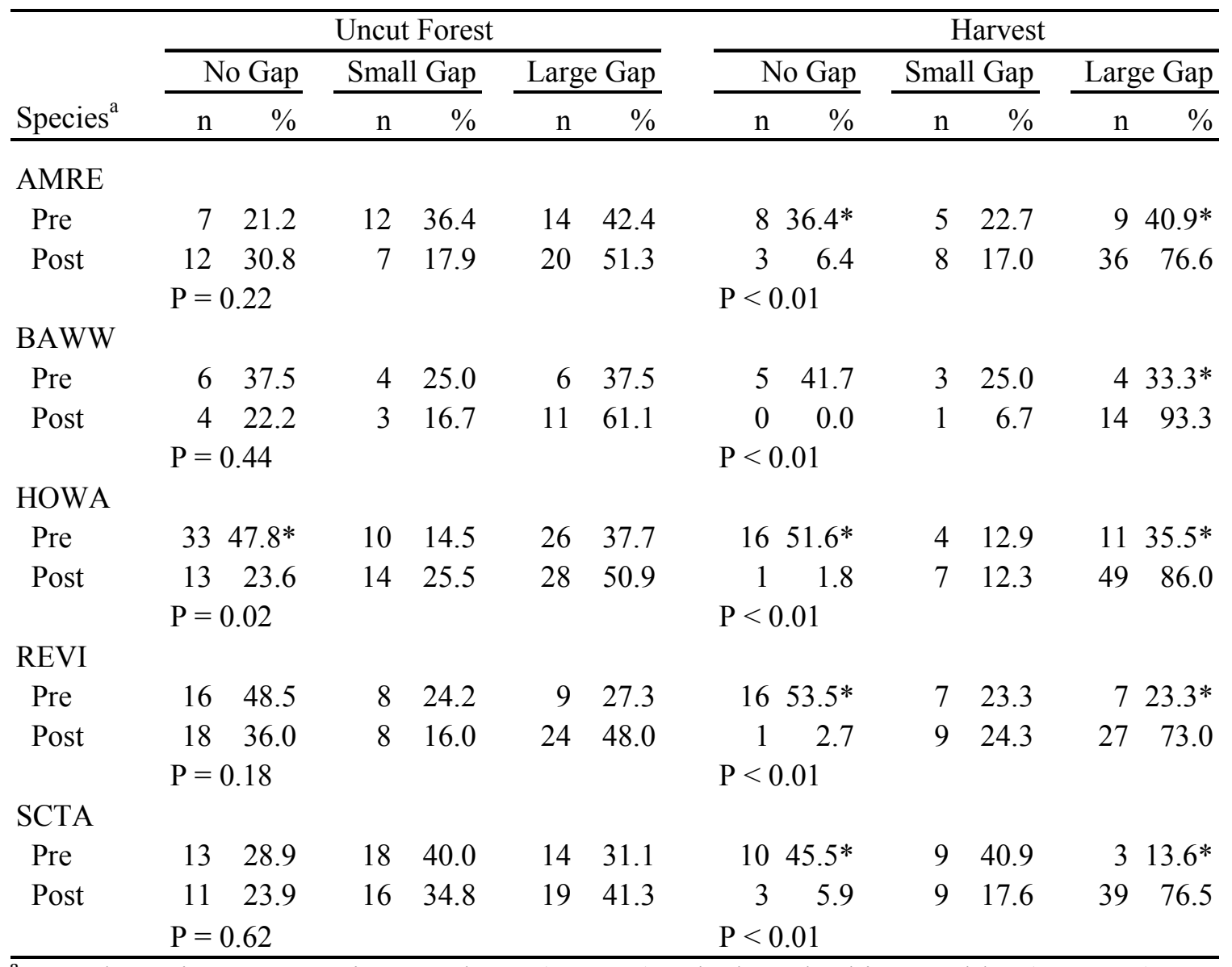

${ }^{a}$ Focal species are American Redstart (AMRE), Black-and-white Warbler (BAWW), Hooded Warbler (HOWA), Red-eyed Vireo (REVI), and Scarlet Tanager (SCTA). 
Table 5: Tree species preference index combining all avian species and plots for the Lewis Wetzel and Wyoming study sites for the pre- (2006) and post-treatment (2007) seasons.

\begin{tabular}{|c|c|c|}
\hline Tree Species & Pre & Post \\
\hline American Beech & 1.3 & 7.7 \\
\hline Basswood & -6.3 & -0.9 \\
\hline Black Gum & 5.5 & -0.8 \\
\hline Chestnut Oak & 16.3 & -22.0 \\
\hline Cucumber Magnolia & -8.7 & -2.5 \\
\hline Hickory Group $^{a}$ & -0.8 & 3.6 \\
\hline Red Maple & 8.7 & -0.3 \\
\hline Red Oak Group ${ }^{a}$ & -31.0 & -44.2 \\
\hline Sugar Maple & 55.0 & 69.1 \\
\hline Tulip Poplar & -21.7 & 7.4 \\
\hline White Ash & -3.9 & -6.9 \\
\hline White Oak & 0.1 & 5.1 \\
\hline $\mathrm{n}=$ & 276 & 356 \\
\hline$\chi^{2}=$ & 60.3 & 68.0 \\
\hline $\mathrm{P}=$ & $<0.01$ & $<0.01$ \\
\hline
\end{tabular}

${ }^{\mathrm{a}}$ Hickory and red oak categories are comprised of all members of their respective groups due to inconsistency in tree species identification. 
Table 6: Tree species preference index for each harvest treatment for all avian species and plots for the Lewis-Wetzel and Wyoming study sites for the pre- (2006) and post-treatment (2007) seasons.. Focal species are American Redstart (AMRE), Black-and-white Warbler (BAWW), Hooded Warbler (HOWA), Red-eyed Vireo (REVI), and Scarlet Tanager (SCTA). All species were combined for analysis.

\begin{tabular}{|c|c|c|c|c|c|c|}
\hline \multirow[b]{2}{*}{ Tree Species } & \multicolumn{2}{|c|}{$\begin{array}{c}\text { Light } \\
\text { Treatment }\end{array}$} & \multicolumn{2}{|c|}{$\begin{array}{c}\text { Intermediate } \\
\text { Treatment }\end{array}$} & \multicolumn{2}{|c|}{$\begin{array}{l}\text { Uncut } \\
\text { Forest }\end{array}$} \\
\hline & Pre & Post & Pre & Post & Pre & Post \\
\hline American Beech & 2.0 & 2.0 & -2.4 & 1.2 & 2.2 & 4.9 \\
\hline Basswood & -1.9 & 2.3 & 0.1 & -2.0 & -0.7 & -1.6 \\
\hline Black Gum & 1.3 & 0.7 & 2.8 & -2.0 & 2.2 & 0.2 \\
\hline $\begin{array}{l}\text { Chestnut Oak } \\
\text { Cucumber }\end{array}$ & 2.4 & -3.9 & 13.2 & -2.5 & 1.5 & -12.2 \\
\hline Magnolia & -2.6 & -3.6 & -3.2 & -1.3 & -2.3 & -0.1 \\
\hline Hickory Group $^{a}$ & -1.3 & -2.6 & -0.5 & 0.6 & 3.6 & 3.9 \\
\hline Red Maple & 0.7 & 0.5 & 1.7 & 1.3 & 5.3 & -3.4 \\
\hline Red Oak Group $^{a}$ & -5.0 & -19.1 & -6.2 & -8.1 & -18.6 & -19.6 \\
\hline Sugar Maple & 9.3 & 22.1 & 3.3 & 8.3 & 26.8 & 39.4 \\
\hline Tulip Poplar & -3.6 & 2.3 & -4.9 & 3.2 & -10.4 & 4.9 \\
\hline White Ash & 0.5 & 1.0 & -0.8 & -1.1 & -2.4 & -4.1 \\
\hline White Oak & -0.3 & 0.3 & -0.4 & 1.9 & 0.8 & 1.3 \\
\hline $\mathrm{n}=$ & 44 & 76 & 56 & 90 & 176 & 190 \\
\hline$x^{2}=$ & 21.9 & 38.8 & 19.0 & 12.2 & 27.3 & 37.5 \\
\hline $\mathrm{P}=$ & 0.45 & $<0.01$ & 0.95 & 0.54 & 0.01 & $<0.01$ \\
\hline
\end{tabular}

${ }^{a}$ Hickory and red oak categories are comprised of all members of their respective groups due to inconsistency in tree species identification. 
Table 7: Tree species preference index for each avian species pre- and post-harvest. Included are Chi-square analysis with Monte Carlo simulated p-values comparing observer and expected frequencies of tree species use by five Neotropical migratory songbirds. Focal species are American Redstart (AMRE), Black-and-white Warbler (BAWW), Hooded Warbler (HOWA), Red-eyed Vireo (REVI), and Scarlet Tanager (SCTA).

\begin{tabular}{|c|c|c|c|c|c|c|c|c|c|c|}
\hline \multirow[b]{2}{*}{ Tree Species } & \multicolumn{2}{|c|}{ AMRE } & \multicolumn{2}{|c|}{ BAWW } & \multicolumn{2}{|c|}{ HOWA } & \multicolumn{2}{|c|}{ REVI } & \multicolumn{2}{|c|}{ SCTA } \\
\hline & Pre & Post & Pre & Post & Pre & Post & Pre & Post & Pre & Post \\
\hline American Beech & -0.59 & 1.76 & -0.66 & 0.19 & 0.76 & 2.48 & 2.11 & 2.81 & -0.86 & 0.48 \\
\hline Basswood & 0.55 & 0.52 & -1.02 & -0.25 & -3.98 & 0.09 & -0.90 & 0.60 & -1.86 & -1.91 \\
\hline Black Gum & 0.06 & -0.27 & 2.19 & -0.46 & 1.06 & 1.57 & 2.70 & -1.25 & -1.26 & -0.43 \\
\hline Chestnut Oak & 2.41 & -11.87 & 0.42 & 6.37 & 0.54 & -7.46 & 5.84 & -2.58 & 3.98 & -6.46 \\
\hline Cucumber Magnolia & -1.33 & 0.71 & 0.03 & -0.82 & -4.74 & -1.57 & -2.76 & 0.76 & -0.72 & -1.57 \\
\hline Hickory Group $^{\mathrm{a}}$ & 3.97 & -1.11 & 0.49 & -0.64 & -6.26 & 2.64 & -2.14 & 2.11 & 0.96 & 0.64 \\
\hline Red Maple & 0.34 & -0.62 & 2.06 & 0.62 & 7.52 & 0.56 & -0.52 & 1.53 & -2.44 & -2.44 \\
\hline Red Oak Group $^{a}$ & -7.83 & -12.09 & -2.68 & -3.43 & -9.96 & -8.96 & -7.45 & -10.75 & -6.30 & -8.96 \\
\hline Sugar Maple & 5.66 & 13.74 & 2.78 & 1.03 & 7.14 & 16.72 & 16.68 & 15.92 & 20.77 & 21.72 \\
\hline Tulip Poplar & 2.21 & 12.86 & -1.66 & -0.36 & -6.86 & -4.64 & -10.40 & -1.86 & -8.25 & 1.36 \\
\hline White Ash & -1.46 & -1.71 & -0.61 & -0.62 & -2.97 & -1.92 & 0.27 & -1.67 & 0.30 & -0.92 \\
\hline White Oak & -0.64 & -0.94 & 0.31 & 0.30 & -1.34 & -1.18 & 0.05 & 1.10 & 1.08 & 5.82 \\
\hline $\mathrm{n}=$ & 49 & 75 & 22 & 30 & 83 & 81 & 59 & 80 & 63 & 90 \\
\hline$\chi^{2}=$ & 12.4 & 37.3 & 7.5 & 6.9 & 20.1 & 22.9 & 32.0 & 24.8 & 25.2 & 24.3 \\
\hline $\mathrm{P}=$ & 0.98 & 0.02 & 0.99 & 0.99 & 0.32 & 0.32 & 0.02 & 0.02 & 0.06 & 0.06 \\
\hline
\end{tabular}

${ }^{\mathrm{a}}$ Hickory and red oak categories are comprised of all members of their respective groups due to inconsistency in tree species identification 


\section{CHAPTER 4}

Analysis of observer detection bias in avian foraging behavior and tree species use. 


\begin{abstract}
Foraging ecology studies could be biased due to disparity in initial detection probabilities of foraging birds among tree species or foraging behaviors because it might be easier to detect a foraging bird when it is in certain tree species, lower in the canopy, or using aerial foraging maneuvers. Our study investigated whether the initial foraging observation is biased based on 1521 paired, single-point foraging observations for six species of arboreal foraging Neotropical migrants in two study sites in West Virginia and one in Kentucky in 2006 and 2007. We did not detect a significant difference in tree species used for foraging between the initial and second foraging observation $(\mathrm{P} \geq 0.62)$. Foraging maneuvers and foraging height generally were not significantly different $(\mathrm{P} \geq 0.09)$ between the two foraging observations for the six avian species tested. We conclude that the initial detection of foraging birds would not have a major influence on interpretation of foraging substrate or behavioral preferences.
\end{abstract}

Key Words: foraging, Neotropical migrant, observer bias, study design, substrate selection 
Much of the literature on design of avian foraging studies has examined autocorrelation in sequential versus single-point foraging observations (Bell et al. 1990, Hejl et al. 1990, Noon and Block 1990, Recher and Gebski 1990), the two standard methods of quantifying avian foraging behavior (Wagner 1981, Bell et al. 1990, Hejl et al. 1990). With single-point observations, only the initial foraging maneuver is recorded. For sequential observations, individual birds are followed for a variable period of time while recording every foraging maneuver implemented (Bell et al. 1990). The single-point method avoids statistical issues associated with independence among observations (Hejl et al. 1990), although Morrison (1984) determined that this method under represents comparatively rare foraging behaviors. Hejl et al. (1990) found that the degree of concealing cover did not influence whether an individual could be followed from initial to subsequent foraging observations; however, they did not evaluate if visibility bias was associated with the initial versus subsequent detection. It might be easier to detect a bird when it is foraging in certain tree species, lower in the canopy, or using aerial foraging maneuvers, all of which could influence interpretation of avian foraging preferences.

Thus, it is important to understand if initial detection probability introduces bias into studies of foraging ecology. Our study investigated whether the initial foraging observation introduced detection bias for six species of arboreal foraging Neotropical migrants by comparing an initial to a second single-point foraging observation to determine if the initial foraging detection unduly influenced interpretation of tree species selection, foraging maneuver used, or vertical height of the foraging individual. The study of a second observation being compared to the first to quantify differential rates of detection among tree species is lacking in the foraging literature. 


\section{METHODS}

Study area. We conducted the study in 2006 and 2007 on three study areas including the Lewis Wetzel Wildlife Management Area (LWWMA) in Wetzel County, West Virginia, forested private timberlands in Wyoming County, West Virginia (Wyoming), and the Daniel Boone National Forest (DBNF) in Bath and Menifee counties, Kentucky. In 2006, all three sites were predominantly mature, second-growth mixed, mesophytic and northern hardwood forests. Predominant tree species at LWWMA and DBNF included maple sp. (Acer sp.), oak sp. (Quercus sp.), hickory sp. (Carya sp.), and tulip poplar (Liriodendron tulipifera). The Wyoming site had tree species similar to the other study areas, although maples were a less significant component. Elevation at the Wyoming site was 400-650 m, while DBNF and LWWMA were 200-400 m. All three study areas are characterized by narrow valleys with steep slopes and convoluted ridges with no prevailing orientation.

Four, 20 ha plots were placed along ridge-tops on northern and eastern aspects at each site. The central 10 ha of each plot was randomly assigned one of four timber harvesting treatments: an unharvested control, a light treatment similar to a single tree selection harvest, an intermediate treatment approximating a shelterwood harvest, and a heavy treatment approximating a deferment harvest. Timber harvests were implemented in fall and winter of 2006.

Foraging observations. We searched each 20 ha plot for foraging Neotropical migrants between 1 May and 15 July, 2006 and 2007. Focal species on the two West Virginia sites were Cerulean Warbler (Dendroica cerulea), Hooded Warbler (Wilsonia citrine), Black-and-white Warbler (Mniotilta varia), American Redstart (Setophaga ruticilla), Red-eyed Vireo (Vireo olivaceus), 
and Scarlet Tanager (Piranga olivacea). At the Kentucky site, observations were recorded only on the Cerulean Warbler.

For each foraging bird located, we collected two single-point foraging observations. The single-point method was used to avoid statistical issues associated with independence of observations (Hejl et al. 1990). When a foraging bird was first detected, the observer waited 5 seconds before recording data for the first foraging observation to avoid bias associated with obvious maneuvers (Hejl et al. 1990). For the second foraging observation, the observer followed the bird to the next tree it selected. We recorded sex when possible and species of the bird, tree species occupied, height within the canopy, and foraging maneuver implemented.

Multiple foraging observations per individual per day were recorded with a minimum of 60 minutes between observations. The 60 minute window allows for statistical independence among observations; 1 minute windows have been considered a biologically independent timeframe for Neotropical migrants (Barg et al. 2005).

We defined two aerial foraging maneuvers and two near-perch maneuvers similar to Remsen and Robinson (1990). The aerial maneuvers were aerial hawk, the traditional flycatcher maneuver, and sally-glean, which is used to secure sessile prey on vegetative surfaces. The nearperch maneuvers were vegetation pick and woody pick.

Foraging height within the tree was assigned one of five height categories based on $\%$ relative height. By using $\%$ relative height rather than actual height within the canopy, we accounted for variability of forest structure within and among research locations (Terborgh 1980).

Statistical Analysis. We summed the total number of foraging observations in each tree species for each bird species. Then we compared frequency of tree species used in the first and 
second observation with a Generalized Cochran-Mantel-Haenszel test $(\mathrm{CMH})$, similar to a threedimensional contingency table (Faraway 2006, R Development Core Team 2007), for each West Virginia site. The $\mathrm{CMH}$ test allowed us to test for variation in tree species use while accounting for different bird species in a single test (Faraway 2006) reducing our chances of committing a Type I statistical error (Zar 1999). For the Kentucky site, we used contingency $\chi^{2}$ test of homogeneity (Conover 1999) to compare first and second foraging observations for Cerulean Warblers. Although within-site variation of tree species was reduced by clustering the four plots on each study area, the study areas were distant from each other and tree species availability differed. Therefore, we analyzed study areas separately. Only tree species that were used at least 5 times per year were included in the $\chi^{2}$ test of homogeneity analysis to avoid a large proportion of zero values (Gabbe et al. 2002).

To compare frequency of foraging maneuver and foraging height between first and second foraging observations, we summed the number of detections for each foraging maneuver and each foraging height category by species, study area, and year for each paired observation. We used the $\mathrm{CMH}$ test to compare distribution of observations among the foraging parameters for the first and second observation while accounting for study area in one step to avoid the need to individually test each contingency table by study site (Faraway 2006).

Years were analyzed separately for all tests because timber harvesting altered forest structure. Because our objective was to compare the distribution across tree species and foraging maneuvers for the paired observations not if use of a particular tree species or maneuver differed, we did not follow the overall $\chi^{2}$ or CMH tests with pair-wise comparisons to separate means. Analyses were completed using the R statistical language (R Development Core Team 2007). We considered differences significant at $\alpha=0.05$. 


\section{RESULTS}

We collected 709 paired foraging observations in 2006 and 812 in 2007 . Distribution of foraging observations among tree species was not different for the first versus second observation at any study site for either year (Table 1). As an example, Cerulean Warbler use of the six most common trees at LWWMA in 2007 was almost identical for the first and second observation (Fig. 1).

With one exception, distribution of foraging maneuvers used was not significantly different between the two foraging observations (Table 2). Use of foraging maneuvers differed between the paired observations only for the American Redstart in 2007 (Table 2).

Similarly, the distribution of detections among foraging height categories was not significantly different between the two foraging observations with one exception (Table 2). In 2006, Red-eyed Vireo use of foraging height categories differed between the two foraging observations.

\section{DISCUSSION}

Because we detected no differences in use of tree species between the paired foraging observations, observer bias in the initial detection of foraging birds did not appear to influence interpretation of foraging substrate preference. Even after timber harvesting, with a more open

canopy structure, tree species use during the two foraging observations remained the same. As a result, the first foraging observation appears to be sufficient in quantifying tree species use in foraging birds. 
We saw a limited number of statistically significant results in analyses of foraging maneuver and foraging height among paired observations (Table 2). Only two species had significant results and only in one season for each species; potentially due to the underlying influence associated with variation detected among comparatively rare foraging maneuvers and heights for those two species. This is somewhat expected considering Morrison (1984) determined that the single-point method is a poor measure of comparatively rare foraging behaviors.

Hejl et al. (1990) suggested that observers wait 5 seconds before recording any behavior to avoid statistical biases associated with obvious maneuvers recorded in the initial foraging detection. Our results suggest that the initial detection of foraging birds also did not influence the interpretation of foraging substrate use. We encourage continued attempts towards the identification of bias in an effort to supplement the sparse literature on the subject while improving the theoretical foundation of avian foraging ecology.

\section{ACKNOWLEDGEMENTS}

Funding for this work was provided by the National Fish and Wildlife Foundation, National Council for Air and Stream Improvement, U.S. Fish and Wildlife Service, West Virginia Division of Natural Resources, Kentucky Department of Fish and Wildlife Resources, and U.S. Forest Service Monongahela National Forest. We thank P. McElhone, P. White, V. Lane, and numerous field technicians for assistance in data collection. We thank S. Durham and L. Skrzypek for logistical support. The West Virginia Division of Natural Resources, Advantage Timberland, Forest Land Group and Wagner LTD, and Daniel Boone National Forest allowed us access to their properties and implemented timber harvests. J. Anderson, P. Keyser, S. Raylman, 
and G. Hobbs provided valuable comments on an earlier draft of this manuscript. Use of trade

names does not imply endorsement by the Federal government.

\section{LITERATURE CITED}

Barg, J. B., J. Jones, and R. J. Robertson. 2005. Describing breeding territories of migratory passerines: suggestions for sampling, choice of estimator, and delineation of core areas. Journal of Animal Ecology 74:139-149.

BELL, G. W., S. J. HeJL, AND J. VERNER. 1990. Proportional use of substrates by foraging birds: model considerations on first sightings and subsequent observations. Studies in Avian Biology 13:161-165.

CONOVER, W. J. 1999. Practical nonparametric statistics. Wiley series in probability and statistics: Applied probability and statistics section. John Wiley \& Sons, Inc., New York, New York.

FARAWAY, J. J. 2006. Extending the linear model with R: Generalized linear, mixed effects and nonparametric regression models. Chapman and Hall/ CRC. Boca Raton, Florida.

GABBE, A. P., S. K. RoBInSON, AND J. D. BRAWN. 2002. Tree-species preferences of foraging insectivorous birds: Implications for floodplain forest restoration. Conservation Biology $16: 462-470$.

HEJL, S. J., J. VERNER, AND G. W. BELL. 1990. Sequential versus initial observation in studies of avian foraging. Studies in Avian Biology 13:166-173.

MORRISON, M. L. 1984. Influence of sample size and sampling design on analysis of avian foraging behavior. Condor 86:146-150.

NOON, B. R. AND W. M. BLOCK. 1990. Analytical considerations for study design. Studies in Avian Biology 13:126-133.

R DeVelopment CoRe TEAm 2007. R: A language and environment for statistical computing. R Foundation for Statistical Computing, Vienna, Austria. ISBN 3-900051-07-0, URL http://www.R-project.org.

RECHER, H. F. AND V. GEBSKI. 1990. Analysis of the foraging ecology of eucalypt forest birds: sequential versus single-point observations. Studies in Avian Biology 13:174-180.

REMSEN, J. V., JR. AND S. K. ROBINSON. 1990. A classification scheme for foraging behavior of birds in terrestrial habitats. Studies in Avian Biology 13:144-160. 
TERBORGH, J. 1980. Vertical stratification of a Neotropical forest bird community. Acta XVII International Ornithological Congress 17:1005-1012.

WAGNER, J. L. 1981. Visibility and bias in avian foraging data. Condor 83:263-264.

ZAR, J. H. 1999. Biostatistical Analysis, fourth edition. Prentice Hall, Upper Saddle River, New Jersey. 
Table 1: Within-year variation in tree species selection between the first and second foraging observations for each study site by year.

\begin{tabular}{lccccc}
\hline Study Site & Year & $N$ & Df & $\mathrm{M}^{2} / \chi^{2 \mathrm{a}}$ & $P$ \\
\hline Daniel Boone NF, KY & 2006 & 133 & 3 & 0.6 & 0.90 \\
& 2007 & 158 & 4 & 2.7 & 0.62 \\
Lewis-Wetzel WMA, WV & 2006 & 537 & 25 & 21.3 & 0.67 \\
& 2007 & 802 & 20 & 15.0 & 0.78 \\
Wyoming, WV & & & & & \\
& 2006 & 661 & 20 & 11.6 & 0.93 \\
& 2007 & 521 & 22 & 16.4 & 0.80 \\
\hline
\end{tabular}

${ }^{a} \mathrm{M}^{2}=$ Cochran-Mantel-Haenszel test which accounted for variation among avian species at the two West Virginia sites; $\chi^{2}=$ Chi-square contingency test at the Kentucky site. 
Table 2: Variation in maneuver use and foraging height between paired foraging observations by species and year. The Cochran-Mantel-Haenszel test $\left(\mathrm{M}^{2}\right)$ accounted for variation among study sites.

\begin{tabular}{|c|c|c|c|c|c|c|c|c|}
\hline \multirow[b]{2}{*}{ Year } & \multirow[b]{2}{*}{ Species $^{\mathrm{a}}$} & \multirow[b]{2}{*}{$N$} & \multicolumn{3}{|c|}{ Foraging Maneuver } & \multicolumn{3}{|c|}{ Foraging Height } \\
\hline & & & $\mathrm{df}$ & $\mathrm{M}^{2}$ & $P$ & $\mathrm{df}$ & $\mathrm{M}^{2}$ & $P$ \\
\hline \multirow[t]{6}{*}{2006} & AMRE & 126 & 3 & 5.4 & 0.14 & 4 & 2.1 & 0.71 \\
\hline & BAWW & 60 & 2 & 1.2 & 0.55 & 4 & 4.6 & 0.33 \\
\hline & CERW & 718 & 3 & 6.0 & 0.11 & 4 & 8.7 & 0.35 \\
\hline & HOWA & 222 & 3 & 1.1 & 0.79 & 4 & 1.7 & 0.80 \\
\hline & REVI & 144 & 3 & 6.5 & 0.09 & 4 & 8.4 & 0.02 \\
\hline & SCTA & 148 & 3 & 0.4 & 0.94 & 4 & 6.6 & 0.34 \\
\hline \multirow[t]{6}{*}{2007} & AMRE & 180 & 3 & 8.0 & 0.05 & 4 & 2.4 & 0.66 \\
\hline & BAWW & 66 & 2 & 2.2 & 0.33 & 4 & 3.2 & 0.53 \\
\hline & CERW & 760 & 3 & 6.4 & 0.09 & 4 & 3.7 & 0.45 \\
\hline & HOWA & 234 & 3 & 1.6 & 0.66 & 4 & 8.1 & 0.09 \\
\hline & REVI & 180 & 3 & 2.2 & 0.53 & 4 & 1.7 & 0.80 \\
\hline & SCTA & 204 & 3 & 0.9 & 0.82 & 4 & 2.2 & 0.93 \\
\hline
\end{tabular}

${ }^{a}$ Cerulean Warbler (CERW), Hooded Warbler (HOWA), American Redstart (AMRE),

Black-and-white Warbler (BAWW), Red-eyed Vireo (REVI), Scarlet Tanager (SCTA) 


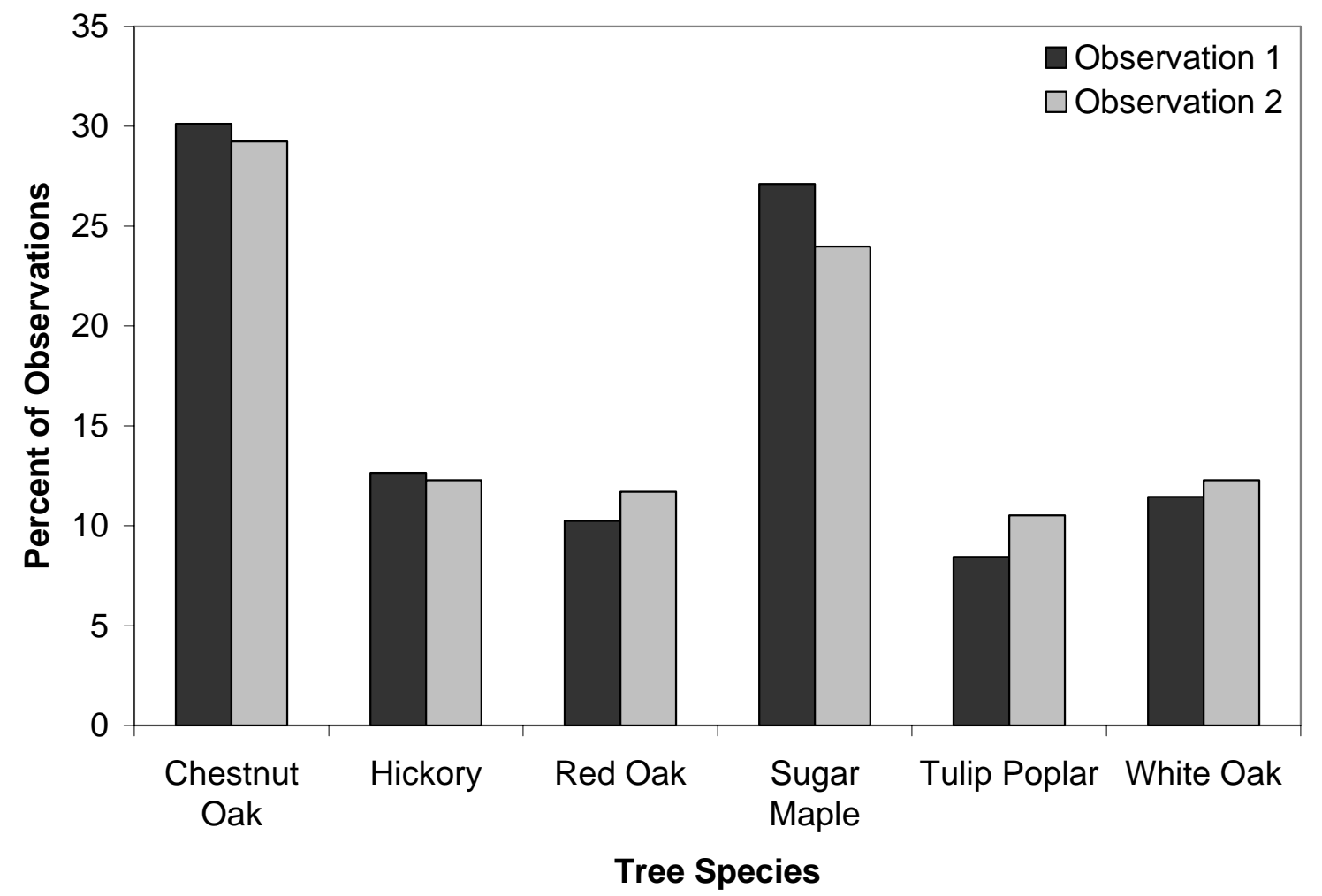

Figure 1: Distribution of Cerulean Warbler foraging observations among tree species at LewisWetzel Wildlife Management Area for 2007. The distribution did not differ for the first versus second observation $\left(\mathrm{M}^{2}=16.4, P=0.80\right)$ at any study site for either year. 


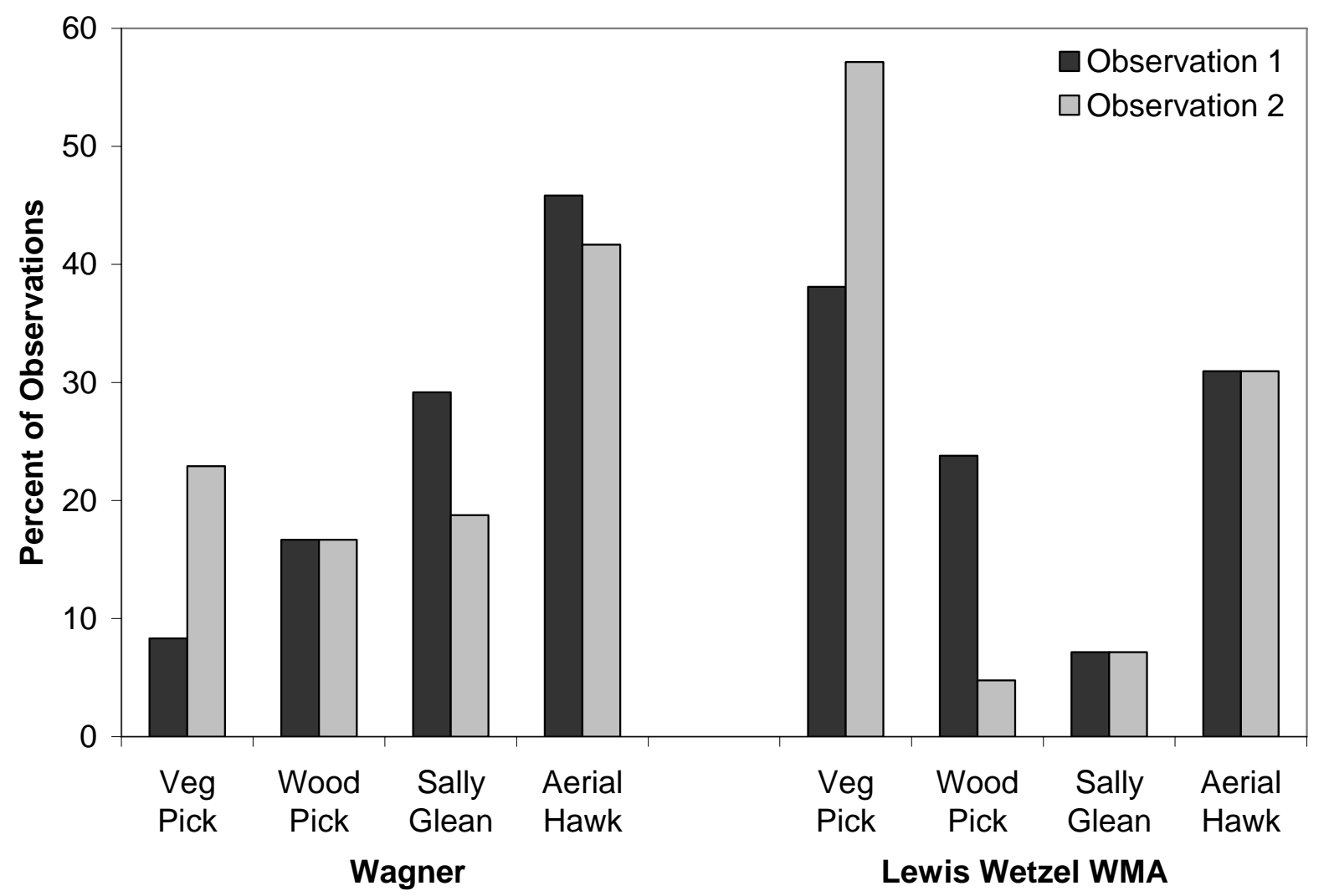

Figure 2: American Redstart use of foraging maneuvers differed between the paired observations in $2007\left(\mathrm{M}^{2}=8.0, P=0.05\right)$. 